OPEN ACCESS

Edited by:

Charlene Kahler,

University of Western Australia,

Australia

Reviewed by:

William William Shafer,

Emory University, United States

Jennifer L. Edwards,

The Ohio State University,

United States

${ }^{*}$ Correspondence:

Vera Kozjak-Pavlovic

vera.kozjak@uni-wuerzburg.de

${ }^{\dagger}$ Present address:

Motaharehsadat Heydarian,

Institute of Lung Biology and Disease (ILBD), Helmholtz Centre Munich,

Munich, Germany

Specialty section:

This article was submitted to

Bacteria and Host,

a section of the journal

Frontiers in Cellular and

Infection Microbiology

Received: 20 December 2021

Accepted: 24 January 2022

Published: 11 February 2022

Citation:

Heydarian M, Rühl E, Rawal R and

Kozjak-Pavlovic V (2022) Tissue

Models for Neisseria gonorrhoeae

Research-From 2D to 3D.

Front. Cell. Infect. Microbiol. 12:840122.

doi: $10.3389 /$ fcimb.2022.840122

\section{Tissue Models for Neisseria gonorrhoeae Research- From 2D to 3D}

\author{
Motaharehsadat Heydarian ${ }^{\dagger}$, Eva Rühl, Ravisha Rawal and Vera Kozjak-Pavlovic * \\ Chair of Microbiology, Biocenter, University of Würzburg, Würzburg, Germany
}

Neisseria gonorrhoeae is a human-specific pathogen that causes gonorrhea, the second most common sexually transmitted infection worldwide. Disease progression, drug discovery, and basic host-pathogen interactions are studied using different approaches, which rely on models ranging from 2D cell culture to complex 3D tissues and animals. In this review, we discuss the models used in N. gonorrhoeae research. We address both in vivo (animal) and in vitro cell culture models, discussing the pros and cons of each and outlining the recent advancements in the field of three-dimensional tissue models. From simple 2D monoculture to complex advanced 3D tissue models, we provide an overview of the relevant methodology and its application. Finally, we discuss future directions in the exciting field of 3D tissue models and how they can be applied for studying the interaction of $N$. gonorrhoeae with host cells under conditions closely resembling those found at the native sites of infection.

\section{Keywords: Neisseria gonorrhoeae, in vivo, in vitro, ex vivo, biomimetic tissue models}

\section{INTRODUCTION}

The sexually transmitted disease (STD) gonorrhea caused by N. gonorrhoeae is the second most common STD which causes around 86.9 million new infections annually around the world, as estimated for 2016 (Rowley et al., 2019). The rapid increase in antibiotic resistance makes gonorrhea a serious threat to public health worldwide (Unemo and Shafer, 2011; Rubin et al., 2020). The mucosal surface of the female cervix and male urethra, anorectal, pharyngeal, and conjunctival areas are the most common sites of N. gonorrhoeae infection (Miller, 2006). N. gonorrhoeae can pass into the deeper tissue layers and reach the bloodstream, causing systemic disseminated gonococcal infections (DGI) in $0.5 \%$ to $3 \%$ of patients, which leads to endocarditis, meningitis, peri hepatitis, and permanent joint damage (Knapp and Holmes, 1975; Cannon et al., 1983; Kerle et al., 1992; Hansen et al., 2014).

History of gonococcal infection research traces back to the use of animal models of rabbits, guinea pigs, hamsters, mice, and chimpanzees (Miller et al., 1945; Lucas et al., 1971; Arko, 1972) (Figure 1). Finding a proper model for gonorrhea research, however, has always been a challenge since $N$. gonorrhoeae is a human-specific pathogen. Several in vitro cell models have been established using various cell sources including cell lines (cancer and immortalized) and primary cells (Shaw and Falkow, 1988; Harvey et al., 1997; Giardina et al., 1998; Scheuerpflug et al., 1999; Christodoulides et al., 2000; Edwards et al., 2000; Hopper et al., 2000; Fichorova et al., 2002). Apart from animal models, 


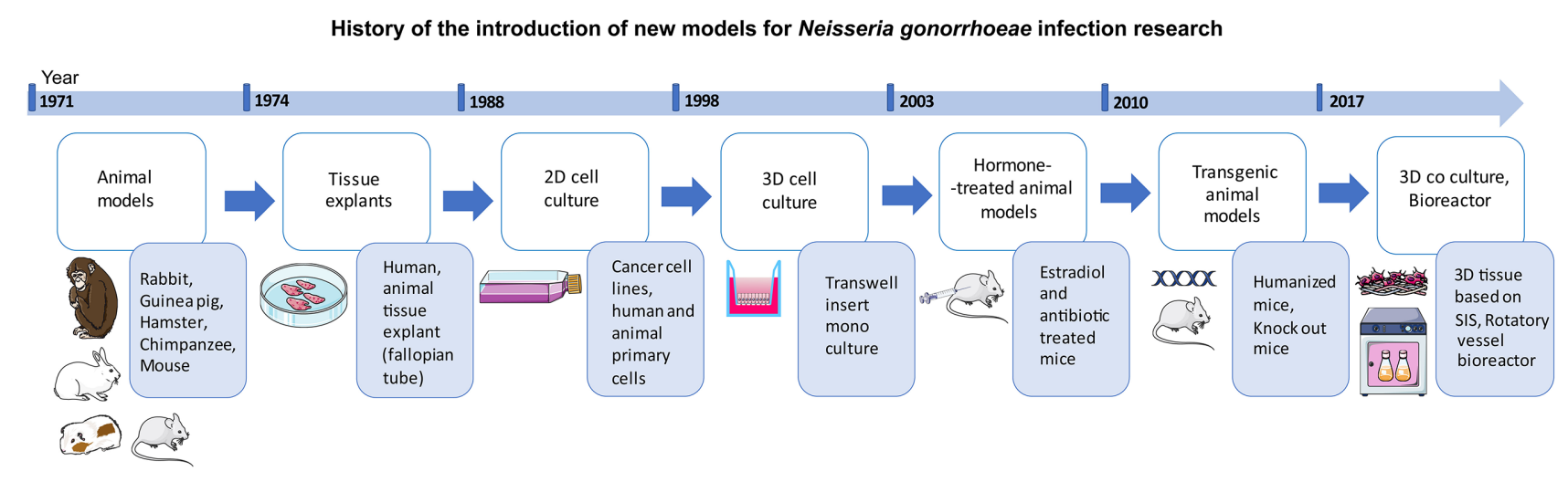

FIGURE 1 | Schematic representation of the history of the introduction of new models into the field of Neisseria gonorrhoeae infection research.

a variety of approaches have been used to recreate the $3 \mathrm{D}$ structure of the site of infection as well as pathogen penetration and immune cell transmigration. These have included: Transwell ${ }^{\circledR}$ insert technology (Merz et al., 1996; Edwards et al., 2000; Stevens et al., 2018), decellularized scaffolds (Heydarian et al., 2019), as well as organ cultures derived from various sites within the urogenital tract (Carney and Taylor-Robinson, 1973; Tjia et al., 1988; Mosleh et al., 1997; Timmerman et al., 2005; Yu et al., 2019). The present review focuses on the established in vivo and in vitro tissue models used in investigations of the infection caused by gonococci. The recent advances in gonorrhea disease research using animal and in vitro/ex vivo tissue models are also reviewed. Finally, we discuss the main challenges and obstacles, followed by future perspectives in the field of models used for studying gonococcal infection.

\section{ANIMAL MODELS}

Human male volunteers have been used as experimental subjects (Cohen et al., 1994; Hobbs et al., 2013) and have helped understand the function of various virulence factors of gonococci as well as the immune response to infection, which can support vaccine research [reviewed in (Hobbs et al., 2011)]. Studies using human-derived source material have provided important insights into the pathogenesis of gonococcal infection in men (Ward and Watt, 1972; Apicella et al., 1996). Nevertheless, due to the ethical limitation, in-depth research of the mechanism of gonococcal infection has mostly relied on animal models, which provide a great tool for studying $N$. gonorrhoeae infection and the corresponding immune response, due to the presence of the intact immune system (Lucas et al., 1971; Arko, 1972; Arko, 1974).

Several non-human species studies, which used rabbits (Miller et al., 1945), guinea pigs (Novotny et al., 1978; Wong et al., 1979), hamsters (Arko, 1972), mice (Streeter and Corbeil, 1981; Johnson et al., 1989), chimpanzees (Lucas et al., 1971; Kraus et al., 1975), or recently greater wax moth larvae (Dijokaite et al., 2021) (Table 1) have been performed to study the disease development and for drug discovery. In 1990, for the first time, Taylor-Robinson and colleagues performed successful colonization of mice with $N$. gonorrhoeae using estradioltreated germ-free female mice (Taylor-Robinson et al., 1990). The $17 \beta$-estradiol treatment promotes the long-term colonization of $N$. gonorrhoeae by the expansion of the estrus phase. However, as during this treatment the overgrowth of commensal flora of mice can prevent the attachment of the gonococci, usage of germ-free mice or antibiotics enhances the success of the colonization by N. gonorrhoeae (Jerse, 1999; Hobbs et al., 2013; Kim et al., 2019). Depending on the type of estradiol treatment, the gonococci can persist in the murine genital tract from 10 to as long as 40 days, but the success of colonization and host response are dependent on the mouse strain used [reviewed in (Jerse et al., 2011)]. Usually, the infection is performed by intravaginal inoculation (Johnson et al., 1989; Taylor-Robinson et al., 1990; Jerse, 1999), or, for the modeling of the upper reproductive tract infection, by transcervical inoculation (Corbeil et al., 1978; Connolly et al., 2021). These mouse models have contributed to the better understanding of the immune response to gonococci (Song et al., 2008; Feinen et al., 2010), and the role of the MtrC-MtrD-MtrE efflux pump system in infection (Jerse et al., 2003; Warner et al., 2007) to name the few examples.

Certain similarities between the physiology of the human and mouse reproductive tract exist. The average vaginal $\mathrm{pH}$ in women is below 4.5, whereas the cervix has a $\mathrm{pH}$ in the range of 6.5 to 7.5 ( $\mathrm{Ng}$ et al., 2018). In comparison, the average vaginal $\mathrm{pH}$ of $17 \beta$-estradiol-treated mice that are susceptible to $N$. gonorrhoeae infection is 6.6, similar to the $\mathrm{pH}$ of the human cervix, which is the primary site of infection for humans (Jerse, 1999; Muench et al., 2009). However, there are also some anatomical and endocrinological differences between mice and men [reviewed in (Cunha et al., 2019)]. For instance, the vaginal flora in mice and humans are dissimilar (Noguchi et al., 2003). Another reason that the mouse model fails to appropriately represent human physiology is the lack of certain host-specific receptors, which are the binding target of different virulence factors of N. gonorrhoeae (Jerse et al., 2011; Quillin and Seifert, 2018). 
TABLE 1 | Selected animal models used for studying N. gonorrhoeae infection.

\begin{tabular}{|c|c|c|}
\hline Animal Model & Key findings & Reference \\
\hline Rabbit & N. gonorrhoeae invade and multiply in the lens and ciliary bodies in the eye of infected rabbits. & (Miller et al., 1945) \\
\hline Chimpanzee & Introducing chimpanzee as a model of choice for studying $N$. gonorrhoeae infection. & (Lucas et al., 1971) \\
\hline Rabbit, guinea pig, hamster, mouse & $\begin{array}{l}\text { Infecting various laboratory animals with } N \text {. gonorrhoeae; introducing guinea pig as the most relevant } \\
\text { model for studying the immune response to } N \text {. gonorrhoeae. }\end{array}$ & $\begin{array}{l}\text { (Arko, 1972) } \\
\text { (Arko, 1974) }\end{array}$ \\
\hline $\begin{array}{l}\mathrm{C} 3 \mathrm{H}, \mathrm{CBA}, \mathrm{BALB} / \mathrm{C}, \mathrm{TO} \text {, and ICR } \\
\text { mice }\end{array}$ & Resistance of mice to gonococcal infection. & $\begin{array}{l}\text { (Johnson et al., } \\
\text { 1989) }\end{array}$ \\
\hline $\begin{array}{l}\text { Estradiol treated germ-free female } \\
\text { BALB/c mice }\end{array}$ & The first evidence of sustained mucosal colonization in mice upon estradiol treatment. & $\begin{array}{l}\text { (Taylor-Robinson } \\
\text { et al., 1990) }\end{array}$ \\
\hline Estradiol treated female BALB/c mice & $\begin{array}{l}\text { The role of mtrCDE-encoded and farAB-encoded efflux pump systems in } N \text {. gonorrhoeae infection in } \\
\text { mice. }\end{array}$ & $\begin{array}{l}\text { (Jerse et al., 2003) } \\
\text { (Warner et al., } \\
\text { 2007) }\end{array}$ \\
\hline $\begin{array}{l}\text { Knockout C57BL/6 BG mice and } \\
\text { THP1 cell line }\end{array}$ & $\begin{array}{l}\text { Investigation of the immune response to } N \text {. gonorrhoeae by focusing on IL-17 and Th17 cells induction } \\
\text { upon infection. }\end{array}$ & $\begin{array}{l}\text { (Feinen et al., } \\
\text { 2010) }\end{array}$ \\
\hline $\begin{array}{l}\text { hCEACAM1 FVB and C57BL/6 BG } \\
\text { transgenic mice }\end{array}$ & Establishment of human CEACAM1 transgenic mouse model. & $\begin{array}{l}\text { (Gu et al., 2010) } \\
\text { (Li et al., 2011) }\end{array}$ \\
\hline $\begin{array}{l}\text { C57BL/6 mice transgenic for human } \\
\text { CEA }\end{array}$ & $\begin{array}{l}\text { Bacteria colonize the urogenital tract of CEA transgenic mice by suppressing the exfoliation of mucosal } \\
\text { cells. }\end{array}$ & $\begin{array}{l}\text { (Muenzner et al., } \\
\text { 2010) } \\
\text { (Muenzner and } \\
\text { Hauck, 2020) }\end{array}$ \\
\hline $\begin{array}{l}\text { Human, estradiol treated female } \\
\text { BALB/c mice }\end{array}$ & $\begin{array}{l}\text { Study of the role of PEA-decorated gonococcal lipid A in competitive infections in female mice and male } \\
\text { volunteers. }\end{array}$ & $\begin{array}{l}\text { (Hobbs et al., } \\
\text { 2013) }\end{array}$ \\
\hline $\begin{array}{l}\text { Transgenic mice (hCEACAM1, } \\
\text { CEABAC2) }\end{array}$ & $\begin{array}{l}\text { The role of individual Opa-CEACAM interactions in uncomplicated lower genital tract infections in } \\
\text { comparison to pelvic inflammatory disease. }\end{array}$ & (Islam et al., 2018) \\
\hline $\begin{array}{l}\text { Human CD34+ stem cell transplanted } \\
\text { NSG mice }\end{array}$ & N. gonorrhoeae co-infection with HIV increases the female genital tract viral shedding. & (Xu et al., 2018) \\
\hline $\begin{array}{l}\text { hCEACAM1, CEABAC2 and } \\
\text { hCEACAM5 transgenic mice }\end{array}$ & $\begin{array}{l}\text { Transcriptional analysis of infected mice; mice diestrus uterine infection shows higher type-1 interferon } \\
\text { induction. }\end{array}$ & $\begin{array}{l}\text { (Francis et al., } \\
\text { 2018) }\end{array}$ \\
\hline Estradiol treated female BALB/c mice & $\begin{array}{l}\text { Commensal species of Neisseria kill Ngo through a mechanism based on genetic competence and DNA } \\
\text { methylation state. }\end{array}$ & (Kim et al., 2019) \\
\hline $\begin{array}{l}\text { An invertebrate Galleria mellonella } \\
\text { greater wax moth larvae }\end{array}$ & Testing of the anti-gonococcal properties of antibiotics and novel antimicrobials. & $\begin{array}{l}\text { (Dijokaite et al., } \\
\text { 2021) }\end{array}$ \\
\hline
\end{tabular}

To address this issue, a variety of humanized transgenic mice has been generated. These express different receptors of gonococcal virulence factors, such as human (h)CEACAM receptors, to increase the similarity of the mouse model to humans (EadesPerner et al., 1994; Gu et al., 2010; Muenzner et al., 2010; Li et al., 2011). Such models were used to show that CEACAM-binding gonococci colonize the urogenital tract of genetically modified mice by suppressing the exfoliation of mucosal cells (Muenzner et al., 2010; Muenzner and Hauck, 2020). Transgenic mice for hCEACAM1, hCEACAM5, and CEABAC2 were also successfully used to reproduce the differential expression of CEACAM1 and CEACAM5 on the surface of the epithelial cell monolayer of the upper and lower female genital tract. This enabled the studies of the effect of Opa-CEACAM mediated interactions during the gonococcal infection along the female genital tract (Islam et al., 2018). Another example of humanized mice models is the engrafting of the immunodeficient NSG mice with human CD34 + hematopoietic stem cells. These mice were used to study $N$. gonorrhoeae and HIV co-infection (Xu et al., 2018).

Although transgenic animals are promising models for studying the early stages of $N$. gonorrhoeae infection (Wang et al., 2008; Gu et al., 2010; Francis et al., 2018), they cannot fully recapitulate all the features of gonorrhea in humans (Wang et al., 2017a; Quillin and Seifert, 2018; Stevens and Criss, 2018). Nevertheless, only a few non-transgenic animal models such as chimpanzees were successfully infected by $N$. gonorrhoeae and showed a greater resemblance of the symptoms and host reaction (Kraus et al., 1975). However, the application of primate models is limited due to the low availability and high maintenance costs (DiGiacomo et al., 1977; Jerse, 1999). In conclusion, the most abundant animal models used in the field of gonorrhea research are estradiol-treated wild-type and transgenic mice expressing human receptors (Table $\mathbf{1}$ ).

\section{IN VITRO 2D CELL MODELS}

Over the past fifty years, a great majority of research on $N$. gonorrhoeae pathogenesis has been conducted using $2 \mathrm{D}$ cell culture of cell lines and primary cells (Table 2). In these in vitro models, cells are normally cultured on cell culture well plates, with and without coating with extracellular matrix (ECM) proteins such as collagen and Matrigel (Harvey et al., 1997; Christodoulides et al., 2000; Simons et al., 2005). Commonly used epithelial cell lines include HeLa cells (Brodeur et al., 1977; Gray-Owen et al., 1997; Naumann et al., 1997), human endometrial adenocarcinoma cells (HEC-1-B) (Shaw and Falkow, 1988), epidermoid carcinoma cervix cells ME180 (Naumann et al., 1997), human colorectal carcinoma cells (T84) (Merz et al., 1996), human conjunctiva epithelial cells (Chang) (Grassmé et al., 1996), and human Asian endometrial adenocarcinoma cells (Ishikawa) (Rodríguez-Tirado et al., 2012). 
TABLE 2 | Selected in vitro 2D cell culture models for studying N. gonorrhoeae infection.

\begin{tabular}{|c|c|c|}
\hline Cells & Key Findings & Reference \\
\hline Human sperm & The role of pilus in the attachment of gonococci to human sperm. & $\begin{array}{l}\text { (James-Holmquest } \\
\text { et al., 1974) }\end{array}$ \\
\hline HeLa, HEp-2 & Interaction of gonococci with tissue culture cells. & (Brodeur et al., 1977) \\
\hline HEC-1-B cell line & $\begin{array}{l}\text { The HEC-1-B cell line was introduced as a model for studying the invasion of } N \text {. } \\
\text { gonorrhoeae. }\end{array}$ & $\begin{array}{l}\text { (Shaw and Falkow, } \\
\text { 1988) }\end{array}$ \\
\hline Corneal epithelial cells, erythrocytes & $\begin{array}{l}\text { The requirement of interaction between PiLE and PiLC for pilus mediated } \\
\text { adherence of } N \text {. gonorrhoeae to the host. }\end{array}$ & (Rudel et al., 1992) \\
\hline Chang cell line & The role of Opa in rearrangements of the epithelial cell actin cytoskeleton. & $\begin{array}{l}\text { (Grassmé et al., } \\
\text { 1996) }\end{array}$ \\
\hline T84 cell line & $\begin{array}{l}\text { Traversal of polarized epithelium by N. gonorrhoeae. The polarization induced by } \\
\text { growing on Transwell }{ }^{\circledR} \text { inserts. }\end{array}$ & (Merz et al., 1996) \\
\hline HeLa, CHO, HUVECs & Investigation of Opa CD66 interactions and cellular response to N. gonorrhoeae. & $\begin{array}{l}\text { (Gray-Owen et al., } \\
\text { 1997) }\end{array}$ \\
\hline HeLa, ME180, HaCaT keratinocytes & $\begin{array}{l}\text { Activation of NF- } \mathrm{KB} \text { and the transcriptional activation of inflammatory cytokine } \\
\text { genes upon infection of epithelial cells. }\end{array}$ & $\begin{array}{l}\text { (Naumann et al., } \\
\text { 1997) }\end{array}$ \\
\hline Primary urethral epithelial cell & $\begin{array}{l}\text { Development of primary male urethral epithelial cell culture method for studying } \\
\text { gonococcal infection. }\end{array}$ & (Harvey et al., 1997) \\
\hline Primary human endometrial cells & $\begin{array}{l}\text { The role of pili and Opa proteins in interactions of } N \text {. gonorrhoeae with } \\
\text { endometrial cell. }\end{array}$ & $\begin{array}{l}\text { (Christodoulides } \\
\text { et al., 2000) }\end{array}$ \\
\hline Primary ecto- and endo-cervical cells & $\begin{array}{l}\text { Membrane ruffles appear to be induced in response to gonococci. Culturing in 2D } \\
\text { with transfer to Transwell }{ }^{\circledR} \text { inserts. }\end{array}$ & (Edwards et al., 2000) \\
\hline $\begin{array}{l}\text { Endocervical (End1), Ectocervical (Ect1), vaginal (Vk2), and } \\
\text { endothelial (HMEC1) cells }\end{array}$ & $\begin{array}{l}\text { Toll-Like Receptor 4-mediated signaling during the immune response to the } N \text {. } \\
\text { gonorrhoeae infection. }\end{array}$ & $\begin{array}{l}\text { (Fichorova et al., } \\
\text { 2002) }\end{array}$ \\
\hline THUEC immortalized primary urethral cells & Study of the inflammatory cytokine response to gonococcal infection. & (Harvey et al., 2002) \\
\hline Fallopian tube epithelial cells & Gonococcal infection inhibits TNF $\alpha$-induced apoptosis. & (Morales et al., 2006) \\
\hline THCEC immortalized primary cervical cells & Study of the mechanism of gonococcal biofilm formation. & (Falsetta et al., 2009) \\
\hline Ishikawa cell line & $\begin{array}{l}\text { Cell junction disruption in human genital epithelial cells is independent of Opa } \\
\text { and Pili. }\end{array}$ & $\begin{array}{l}\text { (Rodríguez-Tirado } \\
\text { et al., 2012) }\end{array}$ \\
\hline
\end{tabular}

In 1988, Shaw and Falkow reported the first in vitro monoculture model based on HEC-1-B cells for studying the invasion of $N$. gonorrhoeae. Here, the authors were able to document the invasion of gonococci, which was inhibited by cytohalasin D and was not affected by the state of piliation of the bacteria (Shaw and Falkow, 1988). N. gonorrhoeae can also be transmitted from infected mothers to their infants during birth, causing neonatal blindness (Rees et al., 1977; Woods, 2005; Quillin and Seifert, 2018). Therefore, adherence and invasion of gonococci were studied in the cultured human corneal epithelial cells, showing that PilC plays a central role in pilus-mediated adherence of the bacteria (Rudel et al., 1992). Human Chang cells were also used for studying the Opa-mediated invasion of $N$. gonorrhoeae (Grassmé et al., 1996). It is important to note that the Chang cell line, originally thought to be derived from human conjunctiva, was later shown to have been established through contamination with HeLa cells (Lavappa, 1978; Capes-Davis et al., 2010) similar to the Hep-2 cell line (Brodeur et al., 1977). Nevertheless, Chang cells are an important tool for studying the interaction of gonococci with epithelial cells if one is not exploring tissue type-specific effects. For example, the Chang cell line has been used by our department to show the necessity of neutral sphingomyelinase 2 activity for the Por $\mathrm{B}_{\mathrm{IA}}$-dependent invasion of $N$. gonorrhoeae under phosphate-free conditions (Faulstich et al., 2015).

Despite the advantages of immortalized cell lines, which include availability, easy handling, and expansion (Pan et al., 2009), they have their drawbacks, such as being derived from tumor tissues or showing significant changes from the original cell type caused by immortalization and prolonged cultivation.
Alternatively, different in vitro models using primary cells or immortalized primary cells have been established. These include early attempts using human sperm (James-Holmquest et al., 1974) or the cells derived from the urethral epithelium (Harvey et al., 1997; Giardina et al., 1998; Zenni et al., 2000; Harvey et al., 2001; Edwards and Apicella, 2005), as well as the immortalized primary urethral cells (Harvey et al., 2002). Primary urethral epithelial cells were mostly used to provide a model system similar to the native tissues for studying the attachment and invasion of gonococci (Harvey et al., 2001), or cytokine response to infection (Harvey et al., 2002) but in some cases were used to confirm the validity of the observations made in tumor cell lines (Giardina et al., 1998). Primary cells derived from different parts of the female reproductive tract were also used in various studies. Among them are those of cervix (Edwards et al., 2000; Swanson et al., 2001; Edwards et al., 2002; Steichen et al., 2008; Edwards, 2010; Jennings et al., 2011), endometrium (Christodoulides et al., 2000; Timmerman et al., 2005), and fallopian tube (Swanson et al., 2001; Maisey et al., 2003; Morales et al., 2006; Reyes et al., 2007). Additionally, immortalized human cervical epithelial cells were introduced in 2009 and used in studies of gonococcal biofilm formation (Falsetta et al., 2009) as well as studies of $N$. gonorrhoeae interaction with cell surface glycans (Semchenko et al., 2019). Primary cell culture systems proved to be useful for the $N$. gonorrhoeae host cell interaction studies where the role of certain receptors was investigated or where the induction of immune response was studied, as well as for the ultrastructural analysis of infected cells. For example, some cancer cell lines such as HEC-1-B and HeLa were shown not to express CEACAM 
molecules, whereas primary cervical cells, but also ME180 cell line, did (Swanson et al., 2001). Primary cells are also a model of choice when various signaling or cell death pathways are investigated or in gene expression studies (Reyes et al., 2007), because tumor cell lines might be too divergent from the original tissues for these purposes. From the technical view, the fact that most primary cells can be passaged for only a few passages represents a significant drawback. The introduction of immortalized primary cells can offer a solution to this problem while providing a model system that is still closer to the native tissue than tumor cell lines.

Apart from colonizing epithelia, N. gonorrhoeae can cause systemic infections, due to its ability to reach deeper tissue layers and blood stream. During its traversal across tissues, it encounters a variety of non-epithelial cells; therefore, cells residing beneath the epithelium such as fibroblasts and endothelial cells have also been used to investigate host-pathogen interaction (Scheuerpflug et al., 1999; Fichorova et al., 2002). Fibroblasts are responsible for the structure and shape of the connective tissue by producing and secreting the ECM components such as collagen, glycosaminoglycans (GAGs), and proteoglycans (Le and Brown, 2012). In addition to epithelial cells, which are capable of innate responses to infection, including the production of complement components, prostaglandins, and cytokines, and in some cases are hormone-responsive (Schleimer et al., 2007; Hickey et al., 2011), fibroblasts also play a role in pathological and immune responses by producing and responding to various cytokines (Delves and Roitt, 1998; LeBleu and Neilson, 2020). In particular, cervical fibroblasts can change their biomechanical properties in response to different stimuli such as pro-inflammatory cytokines (e.g. IL$1 \beta$ ) and hormones (e.g. progesterone), resulting in differential remodeling of the ECM (Shukla et al., 2018). Studying N. gonorrhoeae infection in a monoculture model of murine fibroblasts showed an increase in the number of viable bacteria recovered from the infected cells up to 48 hours post-infection. This effect was not inhibited by washing, indicating that $N$. gonorrhoeae was attached to and/or internalized by fibroblast cells (Waitkins and Flynn, 1973). Furthermore, it has been shown that the activation of the phosphatidylcholine-specific phospholipase C (PC-PLC) and acid sphingomyelinase (ASM) by N. gonorrhoeae is crucial for the pathogen entry into the human fibroblasts (Grassmé et al., 1997).

Infection with $N$. gonorrhoeae triggers a potent innate immune response, which involves neutrophils (also known as polymorphonuclear leukocytes or PMNs). Several reports showed the presence of viable bacteria in gonorrheal exudates, indicating that PMNs are not able to completely clear gonococci (Johnson and Criss, 2011). Various approaches were used to study the N. gonorrhoeae-neutrophil interaction (Table 3). A variety of neutrophil-like cell lines, such as differentiated human leukemia (HL-60) (Bauer et al., 1999; Pantelic et al., 2004), and human monocytic (THP-1) have been developed. These cell lines retain most of the features of neutrophils. For example, HL-60 cells induced by retinoic acid express CEACAM1 and can phagocyte gonococci (Pantelic et al., 2004) and have been shown to be an appropriate model for N. gonorrhoeae-PMN interaction (Chen and Seifert, 2011). However, HL-60 cells also lack specific granules and fail to show the antimicrobial activity associated with primary cells (Le Cabec et al., 1997). Human neutrophils isolated from blood as primary cell models helped understand the role of virulence factors in pathogen invasion and disruption of immune cell functions (Watt, 1970; Thongthai and Sawyer, 1973; Simons et al., 2005; Stohl et al., 2013; Johnson et al., 2015; Reimer et al., 2016). They were used to show that gonococci are resistant to engulfment by neutrophils and can multiply inside them (Simons et al., 2005), as well as that they can inhibit neutrophil apoptosis and activate the secretion of proinflammatory cytokines (Chen and Seifert, 2011).

The role of other immune cells in gonococcal infection has also been addressed in various studies (Table 3). Macrophage models include murine RAW 264.7 and human U937 and THP-1 cell lines, as well as human monocyte-derived primary macrophages (MDMs), which can be differentiated in vitro towards different phenotypes, M1 or M2 [reviewed in (Escobar et al., 2018)]. U937, THP-1, and MDMs have been used to address the interaction of gonococci with macrophages and show that gonococcal porin can arrest phagosome maturation within the macrophages (Mosleh et al., 1998), which might be connected to the further observations that macrophages represent a niche for gonococcal replication (Château and Seifert, 2016), where bacteria occupy distinct subcellular niches when colonizing these immune cells (Ivanov et al., 2021). A series of works using mouse RAW 264.7 macrophage cell line (Escobar et al., 2013), MDMs (Ortiz et al., 2015), as well as dendritic cells (Zhu et al., 2012) has shown that gonococci induce tolerogenic phenotype in macrophages and dendritic cells so that they cannot induce the proliferation of $\mathrm{T}$ cells. More specifically, the role of different receptors on human dendritic cells, which included C-type lectins MGL and DC-SIGN, in the interaction with N. gonorrhoeae and induction of T cell response has been addressed using human monocyte-derived dendritic cells (van Vliet et al., 2009). Additionally, MDMs were used to demonstrate inflammatory pyroptosis induced by $N$. gonorrhoeae (Ritter and Genco, 2018), and human dendritic cells were used in studies of the connection between gonococcal and HIV-1 infection (Zhang et al., 2005). Lymphocyte models include the usage of chicken DT40 B cells, Jurkat cell line, and primary mouse and human lymphocytes (Table 3). The results stemming from these studies mostly pointed in the direction of gonococcal suppression of $\mathrm{T}$ cell proliferation and $\mathrm{B}$ cell humoral response (Boulton and Gray-Owen, 2002; Pantelic et al., 2005; Lee et al., 2007; Lee et al., 2008; Liu et al., 2012). Gonococcal interaction with memory B cells, which results in a broad, $\mathrm{T}$ cell-independent immunoglobulin response (So et al., 2012) has also been recorded. Regarding immune cells, the findings obtained with cell lines were often confirmed using primary cells, which was necessary to validate the results. However, the availability of primary immune cells is greater than the one of primary epithelial cells. They are therefore more often used in modeling of the gonococcal interaction with the host immune system, their disadvantage being donor variability.

Although primary cells enable us to better mimic the site of infection, their application has been limited due to their short life 
TABLE 3 | Selected in vitro models of immune cells for studying N. gonorrhoeae infection.

\begin{tabular}{|c|c|c|}
\hline Cells & Key Findings & Reference \\
\hline Human and guinea pig primary neutrophils & Bactericidal activity of PMNs on gonococci. & (Watt, 1970) \\
\hline Human and rabbit primary neutrophils & Relation between colony morphology and resistance to phagocytosis. & $\begin{array}{l}\text { (Thongthai and Sawyer, } \\
\text { 1973) }\end{array}$ \\
\hline Human monocyte-derived macrophages & Neisserial porin can arrest phagosome maturation within macrophages. & (Mosleh et al., 1998) \\
\hline Human CD4 ${ }^{+}$T lymphocytes & $\begin{array}{l}\text { Gonococcal Opa proteins can bind to primary } \mathrm{CD}^{+} \mathrm{T} \text { lymphocytes and suppress their } \\
\text { activation and proliferation. }\end{array}$ & $\begin{array}{l}\text { (Boulton and Gray- } \\
\text { Owen, 2002) }\end{array}$ \\
\hline HL-60 cell line & $\begin{array}{l}\text { Retinoic acid treated HL-60 cells express CEACAM1 and can phagocytose Opa- } \\
\text { expressing gonococci. }\end{array}$ & (Pantelic et al., 2004) \\
\hline Human primary neutrophils & Resistance and replication of $N$. gonorrhoeae inside neutrophils. & (Simons et al., 2005) \\
\hline Immature human dendritic cells & $\begin{array}{l}\text { Gonococci activate dendritic cells through TLR2, enhancing HIV-1 infection of these } \\
\text { cells. }\end{array}$ & (Zhang et al., 2005) \\
\hline $\begin{array}{l}\text { Chicken DT40 B cells, B cell-enriched peripheral } \\
\text { blood mononuclear cells }\end{array}$ & $\begin{array}{l}\text { N. gonorrhoeae kills CEACAM1 (CD66a)-expressing human B cells, inhibiting antibody } \\
\text { production. }\end{array}$ & (Pantelic et al., 2005) \\
\hline $\begin{array}{l}\text { Primary human } \mathrm{T} \text { cells, Jurkat-CEACAM1 } \\
\mathrm{CD}^{+} \mathrm{T} \text { cell line }\end{array}$ & Neisseria gonorrhoeae suppresses CD4 ${ }^{+}$T Iymphocyte activation. & $\begin{array}{l}\text { (Lee et al., 2007; Lee } \\
\text { et al., 2008) }\end{array}$ \\
\hline Human dendritic cells & $\begin{array}{l}\text { N. gonorrhoeae lipooligosaccharide variation directs dendritic cell-induced T helper } \\
\text { responses. }\end{array}$ & (van Vliet et al., 2009) \\
\hline HL-60 cell line and human primary neutrophils & N. gonorrhoeae actively inhibits apoptosis and activates NF-KB signaling in neutrophils. & $\begin{array}{l}\text { (Chen and Seifert, } \\
\text { 2011) }\end{array}$ \\
\hline $\begin{array}{l}\text { Mouse bone marrow-derived dendritic cells and } \mathrm{T} \\
\text { lymphocytes }\end{array}$ & $\begin{array}{l}\text { N. gonorrhoeae-exposed dendritic cells fail to elicit antigen-induced } \mathrm{CD}^{+} \mathrm{T} \\
\text { lymphocyte proliferation. }\end{array}$ & (Zhu et al., 2012) \\
\hline Mouse spleen T lymphocytes & $\begin{array}{l}\text { N. gonorrhoeae suppresses Th1/Th2-mediated adaptive immune response through the } \\
\text { TGF- } \beta \text {-dependent mechanism. }\end{array}$ & (Liu et al., 2012) \\
\hline Human B lymphocytes & $\begin{array}{l}\text { Gonococci interact with human IgM memory B cells, activating them and eliciting a } \\
\text { broad, T cells-independent Ig response. }\end{array}$ & (So et al., 2012) \\
\hline Mouse RAW 264.7 macrophage cell line & $\begin{array}{l}\text { N. gonorrhoeae induces a tolerogenic phenotype in macrophages to induce immune } \\
\text { response evasion. }\end{array}$ & (Escobar et al., 2013) \\
\hline Human monocyte-derived macrophages & $\begin{array}{l}\text { N. gonorrhoeae-treated macrophages are unable to induce the proliferation of human } \mathrm{T} \\
\text { cells. }\end{array}$ & (Ortiz et al., 2015) \\
\hline $\begin{array}{l}\text { U937 and THP-1 cell lines, monocyte-derived } \\
\text { macrophages }\end{array}$ & $\begin{array}{l}\text { Interaction of } N \text {. gonorrhoeae and macrophages, and the role of macrophages as a } \\
\text { niche for replication of } N \text {. gonorrhoeae. }\end{array}$ & $\begin{array}{l}\text { (Château and Seifert, } \\
\text { 2016) }\end{array}$ \\
\hline Human monocyte-derived macrophages & $\begin{array}{l}\text { N. gonorrhoeae induces inflammatory pyroptosis in human macrophages in connection } \\
\text { to intracellular LOS. }\end{array}$ & $\begin{array}{l}\text { (Ritter and Genco, } \\
\text { 2018) }\end{array}$ \\
\hline U937 and primary human peripheral monocytic cells & N. gonorrhoeae occupy distinct subcellular niches when colonizing macrophages. & (Ivanov et al., 2021) \\
\hline
\end{tabular}

span, low proliferation rate, cross-contamination during cell isolation, and heterogeneity (Unger et al., 2002; Quillin and Seifert, 2018). Another source of primary cells could be induced pluripotent stem cells (iPSCs). They have already been used to study the related Neisseria species, N. meningitidis, and have proved useful in providing novel insights into meningococcal pathogenesis (Martins Gomes et al., 2019). All in all, the monoculture (2D) cell models provide the basic characteristics of the site of infection and are useful for addressing certain questions. They, however, cannot fully replicate the cellular complexity of a 3D model (Duval et al., 2017; Hoarau-Véchot et al., 2018).

\section{IN VITRO 3D TISSUE MODELS}

\section{Artificial Scaffold}

\section{Intestinal and Urogenital Models}

The transition from $2 \mathrm{D}$ to $3 \mathrm{D}$ cell culture techniques is a crucial step to obtain physiologically relevant tissue models for infection research. The advancements in tissue engineering and bioengineering enabled the development of numerous novel in vitro models of human organs, which can be applied in the field of infectious disease research too (Mills and Estes, 2016; DeCicco RePass et al., 2017).
Transwell $^{\circledR}$ inserts are widely used to culture columnar epithelial cells for studying the mechanism of pathogen transmigration through the polarized epithelial monolayer (Table 4). In 1998, human colorectal carcinoma epithelial cells (T84) were cultured on Transwell ${ }^{\circledR}$ inserts to investigate the role of Opa binding to CD66 receptors in the transcellular traversal of $N$. gonorrhoeae (Wang et al., 1998). In the same year, HEC-1-B cells were seeded on collagen-coated Transwell ${ }^{\circledR}$-COL membranes to study the role of pilus phase variation in $N$. gonorrhoeae transmigration through the epithelial layer (Ilver et al., 1998). The T84 monoculture model was also employed to investigate the role of the cytoskeleton and motor proteins in the transcytosis of N. gonorrhoeae (Wang et al., 2008). HEC-1-B and T84 cells on Transwell $^{\circledR}$ inserts were used as well to study the interaction of gonococci with polarized cells and these studies showed that gonococci weaken the apical junction and polarity of epithelial cells by activating EGFR, which facilitates their transmigration (Edwards et al., 2013). In a more recent study, the role of folliculin in controlling the intracellular survival and trans-epithelial passage of $N$. gonorrhoeae was shown using renal carcinoma epithelial cells (UOK 257) grown on Transwell ${ }^{\circledR}$ inserts (Yang et al., 2020). Therefore, such models allow monitoring bacterial interaction with polarized cells, which is not possible when cells are cultivated in $2 \mathrm{D}$. 
TABLE 4 | Selected 3D in vitro models used for studying N. gonorrhoeae infection.

\begin{tabular}{|c|c|c|c|}
\hline Cells/Tissues & Platform & Key Findings & Reference \\
\hline $\begin{array}{l}\text { Fallopian tube organ } \\
\text { cultures }\end{array}$ & Ex vivo model & $\begin{array}{l}\text { Successful long-term infection of organ culture with N. gonorrhoeae } \\
\text { outside the body. }\end{array}$ & $\begin{array}{l}\text { (Carney and Taylor- } \\
\text { Robinson, 1973) }\end{array}$ \\
\hline $\begin{array}{l}\text { Organ culture of the } \\
\text { human fallopian tube }\end{array}$ & $\begin{array}{l}\text { Human ex vivo model, perfusion } \\
\text { bioreactor }\end{array}$ & $\begin{array}{l}\text { Establishment of the perfusion-based system using human fallopian tubes } \\
\text { for studying } N \text {. gonorrhoeae infection. }\end{array}$ & (Ward et al., 1974) \\
\hline $\begin{array}{l}\text { Fallopian tube organ } \\
\text { cultures }\end{array}$ & Ex vivo model & $\begin{array}{l}\text { Attachment of } N \text {. gonorrhoeae and the resulting damage of the oviduct } \\
\text { mucosa. }\end{array}$ & $\begin{array}{l}\text { (Johnson et al., } \\
\text { 1977) } \\
\text { (McGee et al., 1981) }\end{array}$ \\
\hline $\begin{array}{l}\text { The human cornea in } \\
\text { organ culture }\end{array}$ & Ex vivo model & Thinning of cornea upon infection with gonococci. & (Tjia et al., 1988) \\
\hline Distal ureters, human & Ex vivo model & Studying the mechanisms of colonization and invasion of $N$. gonorrhoeae. & (Mosleh et al., 1997 \\
\hline T84 cell line & Transwell ${ }^{\circledR}$ insert & Traversal of polarized epithelium by $N$. gonorrhoeae. & (Merz et al., 1996) \\
\hline T84 cell line & Transwell ${ }^{\circledR}$ insert & $\begin{array}{l}\text { The role of Opa binding to CD66 receptors in the transcellular traversal of } \\
\text { gonococci. }\end{array}$ & (Wang et al., 1998) \\
\hline $\begin{array}{l}\text { Primary human endo- and } \\
\text { ectocervical cells }\end{array}$ & Transwell ${ }^{\circledR}$ insert & $\begin{array}{l}\text { N. gonorrhoeae can invade endo/ectocervix cells and induce cytoskeletal } \\
\text { rearrangements. }\end{array}$ & $\begin{array}{l}\text { (Edwards et al., } \\
\text { 2000) }\end{array}$ \\
\hline Human endometrium & Ex vivo model & N. gonorrhoeae attach to cilia of endometrial cells. & (Timmerman et al., \\
\hline $\begin{array}{l}\text { T84 and HEC-1-B cell } \\
\text { lines }\end{array}$ & Transwell ${ }^{\circledR}$ insert & $\begin{array}{l}\text { N. gonorrhoeae breaches the apical junction of polarized epithelial cells } \\
\text { for transmigration by activating EGFR. }\end{array}$ & (Edwards et al., \\
\hline $\begin{array}{l}\text { Ex vivo porcine vaginal } \\
\text { mucosa }\end{array}$ & Ex vivo model on Transwell ${ }^{\circledR}$ insert & $\begin{array}{l}\text { Interaction of commensal vaginal microbes with } N \text {. gonorrhoeae; N. } \\
\text { gonorrhoeae grows in the } \mathrm{pH} 5.5 \text { induced by lactic acid. }\end{array}$ & $\begin{array}{l}\text { (Breshears et al., } \\
\text { 2015) }\end{array}$ \\
\hline HEC-1-A cell line & Rotating wall vessel bioreactor & $\begin{array}{l}\text { A bioreactor model was developed for studying N. gonorrhoeae infection } \\
\text { under dynamic conditions. }\end{array}$ & $\begin{array}{l}\text { (Łaniewski et al., } \\
\text { 2017) }\end{array}$ \\
\hline Human endocervix, T84 & $\begin{array}{l}\text { Tissue explants, } \\
\text { Transwell }{ }^{\circledR} \text { insert }\end{array}$ & $\begin{array}{l}\text { N. gonorrhoeae induces non-muscle myosin II-mediated epithelial } \\
\text { exfoliation. }\end{array}$ & (Wang et al., 2017b) \\
\hline End1 cells, PMNs & Transwell ${ }^{\circledR}$ insert (co-culture) & $\begin{array}{l}\text { Neutrophil transmigration is dependent on } N \text {. gonorrhoeae contact with } \\
\text { the epithelium. }\end{array}$ & (Stevens et al., 2018) \\
\hline $\begin{array}{l}\text { SV-HUC-1, HEC-1-B, } \\
\text { T84, dermal fibroblasts }\end{array}$ & $\begin{array}{l}\text { SIS scaffold-based 3D co-culture tissue } \\
\text { model }\end{array}$ & $\begin{array}{l}\text { Development of three novel human 3D tissue co-culture models based } \\
\text { on SIS scaffold for studying gonococcal infection. }\end{array}$ & $\begin{array}{l}\text { (Heydarian et al., } \\
\text { 2019) }\end{array}$ \\
\hline $\begin{array}{l}\text { Cervix, HEC-1-B, T84 cell } \\
\text { lines }\end{array}$ & $\begin{array}{l}\text { Tissue explants, } \\
\text { Transwell }{ }^{\circledR} \text { insert }\end{array}$ & $\begin{array}{l}\text { Properties of cervix epithelial cells and pathogen surface molecules in } \\
\text { infectivity of N. gonorrhoeae. }\end{array}$ & (Yu et al., 2019) \\
\hline Excised bovine cornea & Ex vivo model & Establishment of in vitro eye model for studying N. gonorrhoeae infection. & $\begin{array}{l}\text { (Churchward and } \\
\text { Snyder, 2019) }\end{array}$ \\
\hline UOK257 cell line & Transwell ${ }^{\circledR}$ insert & The importance of folliculin in N. gonorrhoeae infection. & (Yang et al., 2020) \\
\hline $\begin{array}{l}\text { T84/fibroblasts/HUVEC/ } \\
\text { PMNs }\end{array}$ & $\begin{array}{l}\text { SIS scaffold-based 3D co-culture tissue } \\
\text { model, perfusion bioreactor }\end{array}$ & $\begin{array}{l}\text { A model with epithelial, fibroblasts, endothelial cells, and neutrophils using } \\
\text { a perfusion bioreactor. }\end{array}$ & $\begin{array}{l}\text { (Heydarian et al., } \\
\text { 2021) }\end{array}$ \\
\hline
\end{tabular}

Apart from cell lines, primary cells can be cultured in 2D for several passages and seeded on Transwell $^{\circledR}$ inserts for the generation of $3 \mathrm{D}$ models. This was shown for primary endometrial cells (Timmerman et al., 2005) as well as endoand ectocervical cells (Edwards et al., 2000). Combining Transwell ${ }^{\circledR}$ culture systems with organoid technology for $N$. gonorrhoeae research could allow a long-term expansion of primary cells due to specialized culture conditions and their subsequent usage in 3D Transwell ${ }^{\circledR}$ models. Until now, methods for long-term culture of many of the epithelia relevant during $N$. gonorrhoeae infection have been established. These include ecto- and endocervical organoids (Chumduri et al., 2021; Lõhmussaar et al., 2021), endometrial organoids (Boretto et al., 2017; Turco et al., 2017), fallopian tube organoids (Kessler et al., 2015), intestinal organoids (Sato et al., 2009), as well as corneal organoids (Foster et al., 2017). Here, it is worth mentioning the multi-cellular model, containing stromal cells and organoidderived epithelial cells of the endometrium on an artificial porous collagen scaffold, which produced polarized, hormoneresponsive endometrial tissue models (Abbas et al., 2020). This is a fine example of how primary cells obtained by organoid cultivation can be transferred onto a scaffold, producing models of higher complexity, which can be used for various purposes, including infection research.

\section{Corneal Models}

Another common site of N. gonorrhoeae infection is the human cornea (Fransen and Klauss, 1988), for which different 3D models have been developed including cell lines as well as primary cells (Shiju et al., 2020). Some of the models were established using cells derived from pigs (Reichl and MüllerGoymann, 2003), cows (Churchward and Snyder, 2019), or rabbits (Drell et al., 1945). The latter was shown to mimic the natural features of Pseudomonas aeruginosa infection, considering that this pathogen can only invade the cornea connective tissue after prior corneal injury (Alarcon et al., 2009). However, since N. gonorrhoeae is a human-specific pathogen, usage of animal cells can pose a problem and there is a need for human cell-derived models.

The established human models include monocultures using only epithelial cells on Transwell ${ }^{\circledR}$ inserts (Karamichos et al., 2012; Rajaiya et al., 2015) or the generation of corneal stromal equivalents (Ghezzi et al., 2017; Isaacson et al., 2018; Priyadarsini et al., 2018), as well as more complex models including co- 
culture of epithelial, stromal, or endothelial cells together (Zhang et al., 2017; Hutcheon et al., 2019). Even cultures including nerve cells have been developed (Wang et al., 2017c; Sharif et al., 2018). However, these models were not made with infection research in mind. Instead, diverse efforts were taken to replace the in vivo Draize test of eye irritation (Lotz et al., 2016; Lotz et al., 2018), generate $3 \mathrm{D}$ corneal models to use them as grafts in transplant medicine (Sharif et al., 2018), and for investigating specific pathologic conditions such as Keratoconus (Karamichos et al., 2012) or dry-eye disease (Park et al., 2018; Kaluzhny et al., 2020). On the other hand, adaptation and usage of these alreadyexisting models in gonococcal research might provide new insights into the pathology of eye infection with N. gonorrhoeae.

\section{Models Introducing Immune Cells}

The female reproductive tract is comprised of layers of epithelial, stromal, and endothelial cells, providing barriers against pathogen invasion (Reynolds et al., 1992; Wira et al., 2005). Moreover, the presence of recruited immune cells during the pathogen challenge is an important feature of the female reproductive system (Wira et al., 2005). To study the interaction of N. gonorrhoeae with the cells of the immune system, several approaches have been attempted so far. Cell-free Transwell ${ }^{\circledR}$ insert membranes were used to study the trafficking of $N$. gonorrhoeae outer membrane vesicles towards the bone marrow-derived macrophages seeded on the coverslip (Deo et al., 2018). One of the previous reports introduced the usage of a microfluidic device to quantitatively measure the $3 \mathrm{D}$ transmigration of neutrophils during an inflammatory reaction (Han et al., 2012). Transwell ${ }^{\circledR}$ co-culture model of neutrophilepithelial cells offered the opportunity to study the immune cell transmigration across the polarized endocervical (End1) cells in response to $N$. gonorrhoeae (Stevens et al., 2018). Traditionally, in vitro models based on Transwell ${ }^{\circledR}$ and Dunn chambers that were used to study neutrophils consist of a well-in-well system. In these, an endothelial layer is formed on the membrane in the top well, followed by an introduction of inflammatory signals into the bottom well. With the addition of neutrophils to the top well, one can quantify the neutrophil migration to the bottom well. These models allow only end point analysis, and to monitor the real-time neutrophil migration and response more complex models are needed (Richardson et al., 2021).

\section{Decellularized Scaffold}

Natural-based scaffolds such as decellularized tissues derived from heart valves, liver, blood vessel, nerves, skin, skeletal muscle, lung, and intestine are currently being investigated for the generation of in vitro and ex vivo models (Badylak, 2007; Steinke et al., 2014; Doryab et al., 2017; Massie et al., 2017; Wang et al., 2017a; Bölükbas et al., 2019). Acellular scaffolds contain key proteins of the ECM such as collagen, fibronectin, laminin, and in the case of porcine small intestinal scaffold (SIS), provide a mesh with interconnected pores, which offers suitable conditions for cell proliferation and differentiation (Gilbert et al., 2006; Shi and Ronfard, 2013; Wang et al., 2020). Recently, we have established three different co-culture models of epithelial cells and fibroblasts based on T84, HEC-1-B, and male uroepithelial cells (SV-HUC-1) using the SIS scaffold as support. We aimed at mimicking functional and morphological features of the site of the gonococcal infection in the human body, recapitulating both cell-cell and cell-matrix interactions. Investigations of the host cell-pathogen interaction using various bacterial strains and derivatives showed that the established tissue models based on the decellularized SIS scaffold are more resilient to infection, as well as that they support bacterial growth, enabling a longer observation time of up to six days. This makes such models suitable for long-term studies of infection and in this aspect superior to the commercial Transwell ${ }^{\circledR}$ models (Heydarian et al., 2019).

Another level of complexity of the models is introduced by culturing the cells under conditions to which they are subjected in their natural environment. Bioreactors provide wellcontrolled cell culture platforms for supporting cell growth under dynamic culture conditions (Bancroft et al., 2003; Odeleye et al., 2020). In 1974, Ward et al. showed that cilia movements can block the $N$. gonorrhoeae attachment to cell surface using a perfusion-based bioreactor system (Ward et al., 1974). In this study, fallopian tubes derived from the patients were placed inside a perfusion system, where organ culture medium was perfused at the rate of $6 \mathrm{~mL} / \mathrm{h}$, followed by 30-60 minutes of circulation of $N$. gonorrhoeae-containing medium into the whole organ, to study the ability of $N$. gonorrhoeae to attach to and invade into the fallopian tube cells (Ward et al., 1974). In 2017, Łaniewski et al. used a rotating wall vessel (RWV) bioreactor to study the colonization of the endometrium by $N$. gonorrhoeae. They showed that the infection with $N$. gonorrhoeae significantly induced expression of proinflammatory mediators, causing ultrastructural alteration of the epithelial cells (Łaniewski et al., 2017), which corresponds to the clinical findings and qualifies this model for gonococcal infection research. We also utilized a perfusion-based bioreactor system to mimic the blood flow in a triple co-culture tissue model of T84, dermal fibroblasts, and human umbilical vein endothelial cells (HUVECs) for $N$. gonorrhoeae infection. The culture medium was circulated (perfusion rate of $0.5 \mathrm{~mL} / \mathrm{min}$ ) through the apical part (epithelial cells) and the isolated human neutrophils were delivered to the endothelial cells in the basal chamber using a perfusion rate of $2.5 \mathrm{~mL} / \mathrm{min}$. The perfusion-based bioreactor provided the opportunity to study the reverse transmigration of neutrophils, which is not possible under static culture conditions (Heydarian et al., 2021).

Moreover, ex vivo culture of explants, such as those from fallopian tubes (Johnson et al., 1977; McGee et al., 1981), kidney (Mosleh et al., 1997), vaginal mucosa (Breshears et al., 2015), and endocervix (Wang et al., 2017b) has been used in the N. gonorrhoeae research. The use of organ culture offers advantages by filling the gap between primary cell culture and in vivo conditions for answering questions related to microbiota, cell structures, such as cilia, or tissue exfoliation during infection. However, ex vivo culture models suffer from donor to donor variability (Grivel and Margolis, 2009) and depend on the availability of tissues. These issues can be circumvented by the generation of $3 \mathrm{D}$ tissue models of high complexity, containing all cell types relevant for the infection. 
In summary, 3D tissue systems provide a more realistic environment, which more faithfully mimics the site of infection in comparison to $2 \mathrm{D}$ cell culture models. They are also more stable and with a longer cell lifespan, which is beneficial when studying long-term infection. However, certain challenges still need attention, such as batch-to-batch variability when using biological scaffolds, transparency of the tissues, and limited depth of microscopy (Antoni et al., 2015). The advantages of using cell lines when generating $3 \mathrm{D}$ tissue models lie in the availability of the cells, which is coupled to the option of generating a larger number of models with lower variability. However, not all cell lines enable the generation of biomimetic tissue models, or the models generated lack certain aspects of native tissues, such as cilia, glycogen granules, or mucus. Here, primary cells and explants can be a better option, despite the already mentioned problems of the availability of the tissues and donor variability. Finally, the model of choice depends not only on the technical aspects but also on the scientific questions asked.

\section{FUTURE DIRECTION}

Many efforts have been undertaken to develop a suitable model for studying N. gonorrhoeae (Figure 1 and Tables 1-4). Progress in the development of animal models and in vitro tissue models from simple $2 \mathrm{D}$ monoculture to complex $3 \mathrm{D}$ co-culture models has helped us to further our understanding of the pathogenesis of $N$. gonorrhoeae. Since the cells cannot form a multi-dimensional structure in $2 \mathrm{D}$ cell culture, $3 \mathrm{D}$ cell culture has emerged as an alternative to improve the cell microenvironment. Driven by the drawbacks of the animal models such as the lack of human receptors and anatomical differences, transgenic and hormonetreated animal models have been developed. Even though the ex vivo and in vitro models of tissues showed promising results in recapitulating the main characteristics of the site of infection in humans, each of these models has also its disadvantages. The transition between rather simple $2 \mathrm{D}$ monoculture to complex biomimetic co-culture and triple co-culture tissue models can assist us in further comprehending the crosstalk between epithelial cells and immune cells during gonococcal infection. In addition to the epithelial and immune cells, stromal cells have been shown to contribute to the growth of epithelial cells as well as to the tissue response to hormones (Arnold et al., 2001; Bläuer et al., 2005), indicating the importance of co-culturing models of epithelial cells with fibroblasts. Moreover, fibroblasts appeared to be a niche for $N$. gonorrhoeae internalization (Waitkins and Flynn, 1973) and were shown to play a crucial role in the longterm infection of the $3 \mathrm{D}$ co-culture model of epithelial/fibroblast cells (Heydarian et al., 2019), which further emphasizes the necessity of their presence when modeling tissues.

Apart from the cell type and origin, bioreactors and microfluidic platforms also play a key role in the increase of the degree of biomimicry of the tissue models, from static to dynamic. Until now, most of the investigations in the field of Neisseria infection have been performed under static conditions, which ignores the dynamics of the natural environment where infection takes place, such as the urethra of men, or blood stream. Recently, a microfluidic culture model of the human reproductive tract has been introduced, which simulated the endocrine loops between organ modules of the ovary, fallopian tube, uterus, cervix, and liver (Xiao et al., 2017). In addition, a variety of microfluidic systems have been developed to study neutrophil migration, neutrophil extracellular traps, and reactive oxygen species production (Agrawal et al., 2008; Boneschansker et al., 2014; Moussavi-Harami et al., 2016; Yang et al., 2017). Microfluidic devices work well for studying the immune response as they can be customized, require fewer reagents and material, and are ideal for working with primary human cells. One can control the spatiotemporal presentation of signaling molecules and the pathogen added to the system, making them applicable for studying complex interactions. Current developments in the microfluidics models allow one to incorporate live and intact pathogens into the models. This not only increases the significance of neutrophil response but also allows studying the direct interaction between neutrophils and a pathogen. The major advantage of microfluidics devices lies in their ability to allow single-cell analysis amidst neutrophil heterogeneity. Continuous development of such devices will allow extensive insights into signals controlling neutrophil function (Richardson et al., 2021).

Further developments of the tissue models would also include the introduction of the microbiome, which is present in various parts of the human female reproductive system (Chen et al., 2017). A correlation between the microbiome, menstrual cycle, and immune responses of the genital tract has been reported (Rönnqvist et al., 2006; Mirmonsef et al., 2011; Chen et al., 2017). Exploring host-microbiome interactions during the infection would help reveal the protective role of commensal microorganisms against the infection.

Recently developed 3D cell culture models such as organoids of the fallopian tube (Kessler et al., 2015), human endometrium (Boretto et al., 2017; Turco et al., 2017), and cervix (Maru et al., 2020; Chumduri et al., 2021) have opened new avenues in the field of investigations of the pathology of the female reproductive tract, including infection research (Alzamil et al., 2021). Human fallopian tube organoids have been successfully used for studying Chlamydia trachomatis infection (Kessler et al., 2019). Many organoids, however, are formed with the epithelial/luminal surface on the interior, which requires the infection to be performed either by microinjection, by reversion of the organoids, or by disruption of the organoids with reseeding after infection [reviewed in (Aguilar et al., 2021)]. In addition to being used as infection models, organoids can also be a source of primary cells for scaffold-based 3D tissue models, which helps to overcome the problems coupled with the infection of the organoids. This will allow us to take one more step towards obtaining high-fidelity tools for studying gonococcal infection under close to natural conditions. Considering the latest advancements in the generation and development of 3D tissue models, we can say that we are on a good way to achieving that goal. 


\section{AUTHOR CONTRIBUTIONS}

All authors have written parts of the manuscript. $\mathrm{MH}, \mathrm{RR}$, and VK-P have generated tables and the figure. All authors contributed to the article and approved the submitted version.

\section{FUNDING}

This work was funded by the Deutsche Forschungsgemeinschaft (DFG) GRK 2157 "3D Tissue Models for Studying Microbial Infections by Human Pathogens" to VK-P. This publication was

\section{REFERENCES}

Abbas, Y., Brunel, L. G., Hollinshead, M. S., Fernando, R. C., Gardner, L., Duncan, I., et al. (2020). Generation of a Three-Dimensional Collagen Scaffold-Based Model of the Human Endometrium. Interface Focus. 10, 20190079. doi: 10.1098/rsfs.2019.0079

Agrawal, N., Toner, M., and Irimia, D. (2008). Neutrophil Migration Assay From a Drop of Blood. Lab. Chip. 8, 2054-2061. doi: 10.1039/b813588f

Aguilar, C., Alves da Silva, M., Saraiva, M., Neyazi, M., Olsson, I. A. S., and Bartfeld, S. (2021). Organoids as Host Models for Infection Biology - a Review of Methods. Exp. Mol. Med. 53, 1471-1482. doi: 10.1038/s12276-021-00629-4

Alarcon, I., Kwan, L., Yu, C., Evans, D. J., and Fleiszig, S. M. (2009). Role of the Corneal Epithelial Basement Membrane in Ocular Defense Against Pseudomonas Aeruginosa. Infect. Immun. 77, 3264-3271. doi: 10.1128/ iai.00111-09

Alzamil, L., Nikolakopoulou, K., and Turco, M. Y. (2021). Organoid Systems to Study the Human Female Reproductive Tract and Pregnancy. Cell Death Differ. 28, 35-51. doi: 10.1038/s41418-020-0565-5

Antoni, D., Burckel, H., Josset, E., and Noel, G. (2015). Three-Dimensional Cell Culture: A Breakthrough In Vivo. Int. J. Mol. Sci. 16, 5517-5527. doi: 10.3390/ ijms16035517

Apicella, M. A., Ketterer, M., Lee, F. K., Zhou, D., Rice, P. A., and Blake, M. S. (1996). The Pathogenesis of Gonococcal Urethritis in Men: Confocal and Immunoelectron Microscopic Analysis of Urethral Exudates From Men Infected With Neisseria Gonorrhoeae. J. Infect. Dis. 173, 636-646. doi: 10.1093/infdis/173.3.636

Arko, R. J. (1972). Neisseria Gonorrhoeae: Experimental Infection of Laboratory Animals. Science 177, 1200-1201. doi: 10.1126/science.177.4055.1200

Arko, R. J. (1974). An Immunologic Model in Laboratory Animals for the Study of Neisseria Gonorrhoeae. J. Infect. Dis. 129, 451-455. doi: 10.1093/infdis/ 129.4.451

Arnold, J. T., Kaufman, D. G., Seppälä, M., and Lessey, B. A. (2001). Endometrial Stromal Cells Regulate Epithelial Cell Growth In Vitro: A New Co-Culture Model. Hum. Reprod. 16, 836-845. doi: 10.1093/humrep/16.5.836

Badylak, S. F. (2007). The Extracellular Matrix as a Biologic Scaffold Material. Biomaterials 28, 3587-3593. doi: 10.1016/j.biomaterials.2007.04.043

Bancroft, G. N., Sikavitsas, V. I., and Mikos, A. G. (2003). Design of a Flow Perfusion Bioreactor System for Bone Tissue-Engineering Applications. Tissue Eng. 9, 549-554. doi: 10.1089/107632703322066723

Bauer, F. J., Rudel, T., Stein, M., and Meyer, T. F. (1999). Mutagenesis of the Neisseria Gonorrhoeae Porin Reduces Invasion in Epithelial Cells and Enhances Phagocyte Responsiveness. Mol. Microbiol. 31, 903-913. doi: 10.1046/j.1365-2958.1999.01230.x

Bläuer, M., Heinonen, P. K., Martikainen, P. M., Tomás, E., and Ylikomi, T. (2005). A Novel Organotypic Culture Model for Normal Human Endometrium: Regulation of Epithelial Cell Proliferation by Estradiol and Medroxyprogesterone Acetate. Hum. Reprod. 20, 864-871. doi: 10.1093/ humrep/deh722

Bölükbas, D. A., De Santis, M. M., Alsafadi, H. N., Doryab, A., and Wagner, D. E. (2019). The Preparation of Decellularized Mouse Lung Matrix Scaffolds for Analysis of Lung Regenerative Cell Potential. Methods Mol. Biol. 1940, 275295. doi: 10.1007/978-1-4939-9086-3_20 funded by the German Research Foundation (DFG) and the University of Wuerzburg in the funding program Open Access Publishing.

\section{ACKNOWLEDGMENTS}

Artworks in Figure 1 were reproduced and modified from the open-source public database Servier Medical Art (https://smart. servier.com), under a Creative Commons Attribution 3.0 Unported License.

Boneschansker, L., Yan, J., Wong, E., Briscoe, D. M., and Irimia, D. (2014). Microfluidic Platform for the Quantitative Analysis of Leukocyte Migration Signatures. Nat. Commun. 5, 4787. doi: 10.1038/ncomms5787

Boretto, M., Cox, B., Noben, M., Hendriks, N., Fassbender, A., Roose, H., et al. (2017). Development of Organoids From Mouse and Human Endometrium Showing Endometrial Epithelium Physiology and Long-Term Expandability. Development 144, 1775-1786. doi: 10.1242/dev.148478

Boulton, I. C., and Gray-Owen, S. D. (2002). Neisserial Binding to CEACAM1 Arrests the Activation and Proliferation of CD4+ T Lymphocytes. Nat. Immunol. 3, 229-236. doi: 10.1038/ni769

Breshears, L. M., Edwards, V. L., Ravel, J., and Peterson, M. L. (2015). Lactobacillus Crispatus Inhibits Growth of Gardnerella Vaginalis and Neisseria Gonorrhoeae on a Porcine Vaginal Mucosa Model. BMC Microbiol. 15, 276. doi: 10.1186/s12866-015-0608-0

Brodeur, B. R., Johnson, W. M., Johnson, K. G., and Diena, B. B. (1977). In Vitro Interaction of Neisseria Gonorrhoeae Type 1 and Type 4 With Tissue Culture Cells. Infect. Immun. 15, 560-567. doi: 10.1128/iai.15.2.560-567.1977

Cannon, J. G., Buchanan, T. M., and Sparling, P. F. (1983). Confirmation of Association of Protein I Serotype of Neisseria Gonorrhoeae With Ability to Cause Disseminated Infection. Infect. Immun. 40, 816-819. doi: 10.1128/ iai.40.2.816-819.1983

Capes-Davis, A., Theodosopoulos, G., Atkin, I., Drexler, H. G., Kohara, A., MacLeod, R. A., et al. (2010). Check Your Cultures! A List of Cross-Contaminated or Misidentified Cell Lines. Int. J. Cancer. 127, 1-8. doi: 10.1002/ijc.25242

Carney, F. E. Jr., and Taylor-Robinson, D. (1973). Growth and Effect of Neisseria Gonorrhoeae in Organ Cultures. Br. J. Vener Dis. 49, 435-440. doi: 10.1136/ sti.49.5.435

Château, A., and Seifert, H. S. (2016). Neisseria Gonorrhoeae Survives Within and Modulates Apoptosis and Inflammatory Cytokine Production of Human Macrophages. Cell Microbiol. 18, 546-560. doi: 10.1111/cmi.12529

Chen, A., and Seifert, H. S. (2011). Neisseria Gonorrhoeae-Mediated Inhibition of Apoptotic Signalling in Polymorphonuclear Leukocytes. Infect. Immun. 79, 4447-4458. doi: 10.1128/iai.01267-10

Chen, C., Song, X., Wei, W., Zhong, H., Dai, J., Lan, Z., et al. (2017). The Microbiota Continuum Along the Female Reproductive Tract and its Relation to Uterine-Related Diseases. Nat. Commun. 8, 875. doi: 10.1038/s41467-01700901-0

Christodoulides, M., Everson, J. S., Liu, B. L., Lambden, P. R., Watt, P. J., Thomas, E. J., et al. (2000). Interaction of Primary Human Endometrial Cells With Neisseria Gonorrhoeae Expressing Green Fluorescent Protein. Mol. Microbiol. 35, 32-43. doi: 10.1046/j.1365-2958.2000.01694.x

Chumduri, C., Gurumurthy, R. K., Berger, H., Dietrich, O., Kumar, N., Koster, S., et al. (2021). Opposing Wnt Signals Regulate Cervical Squamocolumnar Homeostasis and Emergence of Metaplasia. Nat. Cell Biol. 23, 184-197. doi: 10.1038/s41556-020-00619-0

Churchward, C. P., and Snyder, L. A. S. (2019). In Vitro Models of Eye Infection With Neisseria Gonorrhoeae. Methods Mol. Biol. 1997, 363-376. doi: 10.1007/ 978-1-4939-9496-0_21

Cohen, M. S., Cannon, J. G., Jerse, A. E., Charniga, L. M., Isbey, S. F., and Whicker, L. G. (1994). Human Experimentation With Neisseria Gonorrhoeae: Rationale, Methods, and Implications for the Biology of Infection and Vaccine Development. J. Infect. Dis. 169, 532-537. doi: 10.1093/infdis/169.3.532 
Connolly, K. L., Pilligua-Lucas, M., Gomez, C., Costenoble-Caherty, A. C., Soc, A., Underwood, K., et al. (2021). Preclinical Testing of Vaccines and Therapeutics for Gonorrhea in Female Mouse Models of Lower and Upper Reproductive Tract Infection. J. Infect. Dis. 224, S152-S160. doi: 10.1093/infdis/jiab211

Corbeil, L. B., Wunderlich, A. C., and Braude, A. I. (1978). Technique for Transcervical Intrauterine Inoculation of the Mouse. Lab. Anim. Sci. 28, 314-316.

Cunha, G. R., Sinclair, A., Ricke, W. A., Robboy, S. J., Cao, M., and Baskin, L. S. (2019). Reproductive Tract Biology: Of Mice and Men. Differentiation 110, 4963. doi: 10.1016/j.diff.2019.07.004

DeCicco RePass, M. A., Chen, Y., Lin, Y., Zhou, W., Kaplan, D. L., and Ward, H. D. (2017). Novel Bioengineered Three-Dimensional Human Intestinal Model for Long-Term Infection of Cryptosporidium Parvum. Infect. Immun. 85, e00731-16. doi: 10.1128/iai.00731-16

P. J. Delves and I. M. Roitt (1998) (Eds.) Encyclopedia of Immunology 1998, Academic Press, Elsevier Ltd., Netherlands.

Deo, P., Chow, S. H., Hay, I. D., Kleifeld, O., Costin, A., Elgass, K. D., et al. (2018). Outer Membrane Vesicles From Neisseria Gonorrhoeae Target PorB to Mitochondria and Induce Apoptosis. PLoS Pathog. 14, e1006945. doi: 10.1371/ journal.ppat.1006945

DiGiacomo, R. F., Gale, J. L., Holmes, K. K., and Buchanan, T. M. (1977). Genital Inoculation of Male Baboons With Neisseria Gonorrhoeae. Infect. Immun. 15, 670-671. doi: 10.1128/iai.15.2.670-671.1977

Dijokaite, A., Humbert, M. V., Borkowski, E., La Ragione, R. M., and Christodoulides, M. (2021). Establishing an Invertebrate Galleria Mellonella Greater Wax Moth Larval Model of Neisseria Gonorrhoeae Infection. Virulence 12, 1900-1920. doi: 10.1080/21505594.2021.1950269

Doryab, A., Heydarian, M., Amoabediny, G., Sadroddiny, E., and Mahfouzi, S. (2017). Recellularization on Acellular Lung Tissue Scaffold Using PerfusionBased Bioreactor: An Online Monitoring Strategy. J. Med. Biol. Eng. 37, 53-62. doi: 10.1007/s40846-016-0205-1

Drell, M. J., Miller, C. P., Bohnhoff, M., and Moeller, V. (1945). Experimental Gonococcal Infection of the Rabbit's Eye; Course of the Disease and its Pathology. J. Infect. Dis. 77, 201-215. doi: 10.1093/infdis/77.3.201

Duval, K., Grover, H., Han, L. H., Mou, Y., Pegoraro, A. F., Fredberg, J., et al. (2017). Modeling Physiological Events in 2D vs. 3D Cell Culture. Physiol. (Bethesda). 32, 266-277. doi: 10.1152/physiol.00036.2016

Eades-Perner, A. M., van der Putten, H., Hirth, A., Thompson, J., Neumaier, M., von Kleist, S., et al. (1994). Mice Transgenic for the Human Carcinoembryonic Antigen Gene Maintain its Spatiotemporal Expression Pattern. Cancer Res. 54, 4169-4176.

Edwards, J. L. (2010). Neisseria Gonorrhoeae Survival During Primary Human Cervical Epithelial Cell Infection Requires Nitric Oxide and is Augmented by Progesterone. Infect. Immun. 78, 1202-1213. doi: 10.1128/iai.01085-09

Edwards, J. L., and Apicella, M. A. (2005). I-Domain-Containing Integrins Serve as Pilus Receptors for Neisseria Gonorrhoeae Adherence to Human Epithelial Cells. Cell Microbiol. 7, 1197-1211. doi: 10.1111/j.1462-5822.2005.00547.x

Edwards, J. L., Brown, E. J., Uk-Nham, S., Cannon, J. G., Blake, M. S., and Apicella, M. A. (2002). A Co-Operative Interaction Between Neisseria Gonorrhoeae and Complement Receptor 3 Mediates Infection of Primary Cervical Epithelial Cells. Cell Microbiol. 4, 571-584. doi: 10.1046/j.14625822.2002.t01-1-00215.x

Edwards, J. L., Shao, J. Q., Ault, K. A., and Apicella, M. A. (2000). Neisseria Gonorrhoeae Elicits Membrane Ruffling and Cytoskeletal Rearrangements Upon Infection of Primary Human Endocervical and Ectocervical Cells. Infect. Immun. 68, 5354-5363. doi: 10.1128/iai.68.9.5354-5363.2000

Edwards, V. L., Wang, L. C., Dawson, V., Stein, D. C., and Song, W. (2013). Neisseria Gonorrhoeae Breaches the Apical Junction of Polarized Epithelial Cells for Transmigration by Activating EGFR. Cell Microbiol. 15, 1042-1057. doi: $10.1111 / \mathrm{cmi} .12099$

Escobar, A., Candia, E., Reyes-Cerpa, S., Villegas-Valdes, B., Neira, T., Lopez, M., et al. (2013). Neisseria Gonorrhoeae Induces a Tolerogenic Phenotype in Macrophages to Modulate Host Immunity. Mediators Inflamm. 2013, 127017. doi: $10.1155 / 2013 / 127017$

Escobar, A., Rodas, P. I., and Acuña-Castillo, C. (2018). Macrophage-Neisseria Gonorrhoeae Interactions: A Better Understanding of Pathogen Mechanisms of Immunomodulation. Front. Immunol. 9. doi: 10.3389/fimmu.2018.03044

Falsetta, M. L., Bair, T. B., Ku, S. C., Vanden Hoven, R. N., Steichen, C. T., McEwan, A. G., et al. (2009). Transcriptional Profiling Identifies the Metabolic
Phenotype of Gonococcal Biofilms. Infect. Immun. 77, 3522-3532. doi: 10.1128/iai.00036-09

Faulstich, M., Hagen, F., Avota, E., Kozjak-Pavlovic, V., Winkler, A. C., Xian, Y., et al. (2015). Neutral Sphingomyelinase 2 is a Key Factor for PorB-Dependent Invasion of Neisseria Gonorrhoeae. Cell Microbiol. 17, 241-253. doi: 10.1111/ cmi. 12361

Feinen, B., Jerse, A. E., Gaffen, S. L., and Russell, M. W. (2010). Critical Role of Th17 Responses in a Murine Model of Neisseria Gonorrhoeae Genital Infection. Mucosal Immunol. 3, 312-321. doi: 10.1038/mi.2009.139

Fichorova, R. N., Cronin, A. O., Lien, E., Anderson, D. J., and Ingalls, R. R. (2002). Response to Neisseria Gonorrhoeae by Cervicovaginal Epithelial Cells Occurs in the Absence of Toll-Like Receptor 4-Mediated Signaling. J. Immunol. 168, 2424-2432. doi: 10.4049/jimmunol.168.5.2424

Foster, J. W., Wahlin, K., Adams, S. M., Birk, D. E., Zack, D. J., and Chakravarti, S. (2017). Cornea Organoids From Human Induced Pluripotent Stem Cells. Sci. Rep. 7, 41286. doi: 10.1038/srep41286

Francis, I. P., Islam, E. A., Gower, A. C., Shaik-Dasthagirisaheb, Y. B., Gray-Owen, S. D., and Wetzler, L. M. (2018). Murine Host Response to Neisseria Gonorrhoeae Upper Genital Tract Infection Reveals a Common Transcriptional Signature, Plus Distinct Inflammatory Responses That Vary Between Reproductive Cycle Phases. BMC Genomics 19, 627. doi: 10.1186/ s12864-018-5000-7

Fransen, L., and Klauss, V. (1988). Neonatal Ophthalmia in the Developing World. Epidemiology, Etiology, Management and Control. Int. Ophthalmol. 11, 189-196. doi: 10.1007/bf00130622

Ghezzi, C. E., Marelli, B., Omenetto, F. G., Funderburgh, J. L., and Kaplan, D. L. (2017). 3d Functional Corneal Stromal Tissue Equivalent Based on Corneal Stromal Stem Cells and Multi-Layered Silk Film Architecture. PLoS One 12, e0169504. doi: 10.1371/journal.pone.0169504

Giardina, P. C., Williams, R., Lubaroff, D., and Apicella, M. A. (1998). Neisseria Gonorrhoeae Induces Focal Polymerization of Actin in Primary Human Urethral Epithelium. Infect. Immun. 66, 3416-3419. doi: 10.1128/ iai.66.7.3416-3419.1998

Gilbert, T. W., Sellaro, T. L., and Badylak, S. F. (2006). Decellularization of Tissues and Organs. Biomaterials 27, 3675-3683. doi: 10.1016/j.biomaterials.2006.02.014

Grassmé, H., Gulbins, E., Brenner, B., Ferlinz, K., Sandhoff, K., Harzer, K., et al. (1997). Acidic Sphingomyelinase Mediates Entry of N. Gonorrhoeae Into Nonphagocytic Cells. Cell 91, 605-615. doi: 10.1016/s0092-8674(00)80448-1

Grassmé, H. U., Ireland, R. M., and van Putten, J. P. (1996). Gonococcal Opacity Protein Promotes Bacterial Entry-Associated Rearrangements of the Epithelial Cell Actin Cytoskeleton. Infect. Immun. 64, 1621-1630. doi: 10.1128/ iai.64.5.1621-1630.1996

Gray-Owen, S. D., Lorenzen, D. R., Haude, A., Meyer, T. F., and Dehio, C. (1997). Differential Opa Specificities for CD66 Receptors Influence Tissue Interactions and Cellular Response to Neisseria Gonorrhoeae. Mol. Microbiol. 26, 971-980. doi: 10.1046/j.1365-2958.1997.6342006.x

Grivel, J. C., and Margolis, L. (2009). Use of Human Tissue Explants to Study Human Infectious Agents. Nat. Protoc. 4, 256-269. doi: 10.1038/nprot.2008.245

Gu, A., Zhang, Z., Zhang, N., Tsark, W., and Shively, J. E. (2010). Generation of Human CEACAM1 Transgenic Mice and Binding of Neisseria Opa Protein to Their Neutrophils. PLoS One 5, e10067. doi: 10.1371/journal.pone.0010067

Hansen, L. K., Becher, N., Bastholm, S., Glavind, J., Ramsing, M., Kim, C. J., et al. (2014). The Cervical Mucus Plug Inhibits, But Does Not Block, the Passage of Ascending Bacteria From the Vagina During Pregnancy. Acta Obstet Gynecol Scand. 93, 102-108. doi: 10.1111/aogs.12296

Han, S., Yan, J.-J., Shin, Y., Jeon, J. J., Won, J., Eun Jeong, H., et al. (2012). A Versatile Assay for Monitoring In Vivo-Like Transendothelial Migration of Neutrophils. Lab. Chip. 12, 3861-3865. doi: 10.1039/C2LC40445A

Harvey, H. A., Jennings, M. P., Campbell, C. A., Williams, R., and Apicella, M. A. (2001). Receptor-Mediated Endocytosis of Neisseria Gonorrhoeae Into Primary Human Urethral Epithelial Cells: The Role of the Asialoglycoprotein Receptor. Mol. Microbiol. 42, 659-672. doi: 10.1046/j.1365-2958.2001.02666.x

Harvey, H. A., Ketterer, M. R., Preston, A., Lubaroff, D., Williams, R., and Apicella, M. A. (1997). Ultrastructural Analysis of Primary Human Urethral Epithelial Cell Cultures Infected With Neisseria Gonorrhoeae. Infect. Immun. 65, 2420 2427. doi: 10.1128/iai.65.6.2420-2427.1997

Harvey, H. A., Post, D. M., and Apicella, M. A. (2002). Immortalization of Human Urethral Epithelial Cells: A Model for the Study of the Pathogenesis of and the 
Inflammatory Cytokine Response to Neisseria Gonorrhoeae Infection. Infect. Immun. 70, 5808-5815. doi: 10.1128/iai.70.10.5808-5815.2002

Heydarian, M., Schweinlin, M., Schwarz, T., Rawal, R., Walles, H., Metzger, M., et al. (2021). Triple Co-Culture and Perfusion Bioreactor for Studying the Interaction Between Neisseria Gonorrhoeae and Neutrophils: A Novel 3D Tissue Model for Bacterial Infection and Immunity. J. Tissue Eng. 12, 2041731420988802. doi: 10.1177/2041731420988802

Heydarian, M., Yang, T., Schweinlin, M., Steinke, M., Walles, H., Rudel, T., et al. (2019). Biomimetic Human Tissue Model for Long-Term Study of Neisseria Gonorrhoeae Infection. Front. Microbiol. 10. doi: 10.3389/ fmicb.2019.01740

Hickey, D. K., Patel, M. V., Fahey, J. V., and Wira, C. R. (2011). Innate and Adaptive Immunity at Mucosal Surfaces of the Female Reproductive Tract: Stratification and Integration of Immune Protection Against the Transmission of Sexually Transmitted Infections. J. Reprod. Immunol. 88, 185-194. doi: 10.1016/j.jri.2011.01.005

Hoarau-Véchot, J., Rafii, A., Touboul, C., and Pasquier, J. (2018). Halfway Between 2D and Animal Models: Are 3d Cultures the Ideal Tool to Study Cancer-Microenvironment Interactions? Int. J. Mol. Sci. 19, 181. doi: 10.3390/ ijms19010181

Hobbs, M. M., Anderson, J. E., Balthazar, J. T., Kandler, J. L., Carlson, R. W., Ganguly, J., et al. (2013). Lipid A's Structure Mediates Neisseria Gonorrhoeae Fitness During Experimental Infection of Mice and Men. mBio 4, e00892e00813. doi: 10.1128/mBio.00892-13

Hobbs, M. M., Sparling, P. F., Cohen, M. S., Shafer, W. M., Deal, C. D., and Jerse, A. E. (2011). Experimental Gonococcal Infection in Male Volunteers: Cumulative Experience With Neisseria Gonorrhoeae Strains FA1090 and MS11mkC. Front. Microbiol. 2. doi: 10.3389/fmicb.2011.00123

Hopper, S., Vasquez, B., Merz, A., Clary, S., Wilbur, J. S., and So, M. (2000). Effects of the Immunoglobulin A1 Protease on Neisseria Gonorrhoeae Trafficking Across Polarized T84 Epithelial Monolayers. Infect. Immun. 68, 906-911. doi: 10.1128/iai.68.2.906-911.2000

Hutcheon, A. E. K., Zieske, J. D., and Guo, X. (2019). 3d In Vitro Model for Human Corneal Endothelial Cell Maturation. Exp. Eye Res. 184, 183-191. doi: 10.1016/j.exer.2019.04.003

Ilver, D., Källström, H., Normark, S., and Jonsson, A. B. (1998). Transcellular Passage of Neisseria Gonorrhoeae Involves Pilus Phase Variation. Infect. Immun. 66, 469-473. doi: 10.1128/iai.66.2.469-473.1998

Isaacson, A., Swioklo, S., and Connon, C. J. (2018). 3D Bioprinting of a Corneal Stroma Equivalent. Exp. Eye Res. 173, 188-193. doi: 10.1016/j.exer.2018.05.010

Islam, E. A., Anipindi, V. C., Francis, I., Shaik-Dasthagirisaheb, Y., Xu, S., Leung, N., et al. (2018). Specific Binding to Differentially Expressed Human Carcinoembryonic Antigen-Related Cell Adhesion Molecules Determines the Outcome of Neisseria Gonorrhoeae Infections Along the Female Reproductive Tract. Infect. Immun. 86, e000092-18. doi: 10.1128/iai.00092-18

Ivanov, S. S., Castore, R., Juarez Rodriguez, M. D., Circu, M., and Dragoi, A. M. (2021). Neisseria Gonorrhoeae Subverts Formin-Dependent Actin Polymerization to Colonize Human Macrophages. PLoS Pathog. 17, e1010184. doi: 10.1371/journal.ppat.1010184

James-Holmquest, A. N., Swanson, J., Buchanan, T. M., Wende, R. D., and Williams, R. P. (1974). Differential Attachment by Piliated and Nonpiliated Neisseria Gonorrhoeae to Human Sperm. Infect. Immun. 9, 897-902. doi: 10.1128/iai.9.5.897-902.1974

Jennings, M. P., Jen, F. E., Roddam, L. F., Apicella, M. A., and Edwards, J. L. (2011). Neisseria Gonorrhoeae Pilin Glycan Contributes to CR3 Activation During Challenge of Primary Cervical Epithelial Cells. Cell Microbiol. 13, 885896. doi: $10.1111 / j .1462-5822.2011 .01586 . x$

Jerse, A. E. (1999). Experimental Gonococcal Genital Tract Infection and Opacity Protein Expression in Estradiol-Treated Mice. Infect. Immun. 67, 5699-5708. doi: 10.1128/iai.67.11.5699-5708.1999

Jerse, A. E., Sharma, N. D., Simms, A. N., Crow, E. T., Snyder, L. A., and Shafer, W. M. (2003). A Gonococcal Efflux Pump System Enhances Bacterial Survival in a Female Mouse Model of Genital Tract Infection. Infect. Immun. 71, 5576-5582. doi: 10.1128/iai.71.10.5576-5582.2003

Jerse, A. E., Wu, H., Packiam, M., Vonck, R. A., Begum, A. A., and Garvin, L. E. (2011). Estradiol-Treated Female Mice as Surrogate Hosts for Neisseria Gonorrhoeae Genital Tract Infections. Front. Microbiol. 2. doi: 10.3389/ fmicb.2011.00107
Johnson, M. B., Ball, L. M., Daily, K. P., Martin, J. N., Columbus, L., and Criss, A. K. (2015). Opa+ Neisseria Gonorrhoeae Exhibits Reduced Survival in Human Neutrophils via Src Family Kinase-Mediated Bacterial Trafficking Into Mature Phagolysosomes. Cell Microbiol. 17, 648-665. doi: 10.1111/cmi.12389

Johnson, M. B., and Criss, A. K. (2011). Resistance of Neisseria Gonorrhoeae to Neutrophils. Front. Microbiol. 2. doi: 10.3389/fmicb.2011.00077

Johnson, A. P., Taylor-Robinson, D., and McGee, Z. A. (1977). Species Specificity of Attachment and Damage to Oviduct Mucosa by Neisseria Gonorrhoeae. Infect. Immun. 18, 833-839. doi: 10.1128/iai.18.3.833-839.1977

Johnson, A. P., Tuffrey, M., and Taylor-Robinson, D. (1989). Resistance of Mice to Genital Infection With Neisseria Gonorrhoeae. J. Med. Microbiol. 30, 33-36. doi: 10.1099/00222615-30-1-33

Kaluzhny, Y., Kinuthia, M. W., Lapointe, A. M., Truong, T., Klausner, M., and Hayden, P. (2020). Oxidative Stress in Corneal Injuries of Different Origin: Utilization of 3D Human Corneal Epithelial Tissue Model. Exp. Eye Res. 190, 107867. doi: 10.1016/j.exer.2019.107867

Karamichos, D., Zareian, R., Guo, X., Hutcheon, A. E., Ruberti, J. W., and Zieske, J. D. (2012). Novel in Vitro Model for Keratoconus Disease. J. Funct. Biomater. 3, 760-775. doi: 10.3390/jfb3040760

Kerle, K. K., Mascola, J. R., and Miller, T. A. (1992). Disseminated Gonococcal Infection. Am. Fam Physician. 45, 209-214.

Kessler, M., Hoffmann, K., Brinkmann, V., Thieck, O., Jackisch, S., Toelle, B., et al. (2015). The Notch and Wnt Pathways Regulate Stemness and Differentiation in Human Fallopian Tube Organoids. Nat. Commun. 6, 8989. doi: 10.1038/ ncomms 9989

Kessler, M., Hoffmann, K., Fritsche, K., Brinkmann, V., Mollenkopf, H. J., Thieck, O., et al. (2019). Chronic Chlamydia Infection in Human Organoids Increases Stemness and Promotes Age-Dependent CpG Methylation. Nat. Commun. 10, 1194. doi: 10.1038/s41467-019-09144-7

Kim, W. J., Higashi, D., Goytia, M., Rendón, M. A., Pilligua-Lucas, M., Bronnimann, M., et al. (2019). Commensal Neisseria Kill Neisseria Gonorrhoeae Through a DNA-Dependent Mechanism. Cell Host Microbe 26, 228-239.e228. doi: 10.1016/j.chom.2019.07.003

Knapp, J. S., and Holmes, K. K. (1975). Disseminated Gonococcal Infections Caused by Neisseria Gonorrhoeae With Unique Nutritional Requirements. J. Infect. Dis. 132, 204-208. doi: 10.1093/infdis/132.2.204

Kraus, S. J., Brown, W. J., and Arko, R. J. (1975). Acquired and Natural Immunity to Gonococcal Infection in Chimpanzees. J. Clin. Invest. 55, 1349-1356. doi: $10.1172 /$ jci108054

Łaniewski, P., Gomez, A., Hire, G., So, M., and Herbst-Kralovetz, M. M. (2017). Human Three-Dimensional Endometrial Epithelial Cell Model To Study Host Interactions With Vaginal Bacteria and Neisseria Gonorrhoeae. Infect. Immun. 85, e01049-16. doi: 10.1128/iai.01049-16

Lavappa, K. S. (1978). Survey of ATCC Stocks of Human Cell Lines for HeLa Contamination. In Vitro 14, 469-475. doi: 10.1007/bf02616110

LeBleu, V. S., and Neilson, E. G. (2020). Origin and Functional Heterogeneity of Fibroblasts. FASEB J. 34, 3519-3536. doi: 10.1096/fj.201903188R

Le, A. D., and Brown, J. J. (2012). "Chapter 2 - Wound Healing: Repair Biology and Wound and Scar Treatment," in Current Therapy In Oral and Maxillofacial Surgery. Eds. S. C. Bagheri, R. B. Bell and H. A. Khan (Saint Louis: W.B. Saunders), 6-10.

Le Cabec, V., Calafat, J., and Borregaard, N. (1997). Sorting of the Specific Granule Protein, NGAL, During Granulocytic Maturation of HL-60 Cells. Blood 89, 2113-2121. doi: 10.1182/blood.V89.6.2113

Lee, H. S., Boulton, I. C., Reddin, K., Wong, H., Halliwell, D., Mandelboim, O., et al. (2007). Neisserial Outer Membrane Vesicles Bind the Coinhibitory Receptor Carcinoembryonic Antigen-Related Cellular Adhesion Molecule 1 and Suppress CD4+ T Lymphocyte Function. Infect. Immun. 75, 4449-4455. doi: 10.1128/iai.00222-07

Lee, H. S., Ostrowski, M. A., and Gray-Owen, S. D. (2008). CEACAM1 Dynamics During Neisseria Gonorrhoeae Suppression of CD4+ T Lymphocyte Activation. J. Immunol. 180, 6827-6835. doi: 10.4049/jimmunol.180.10.6827

Li, G., Jiao, H., Yan, H., Wang, J., Wang, X., and Ji, M. (2011). Establishment of a Human CEACAM1 Transgenic Mouse Model for the Study of Gonococcal Infections. J. Microbiol. Methods 87, 350-354. doi: 10.1016/j.mimet. 2011.09.012

Liu, Y., Islam, E. A., Jarvis, G. A., Gray-Owen, S. D., and Russell, M. W. (2012). Neisseria Gonorrhoeae Selectively Suppresses the Development of Th1 and 
Th2 Cells, and Enhances Th17 Cell Responses, Through TGF- $\beta$-Dependent Mechanisms. Mucosal Immunol. 5, 320-331. doi: 10.1038/mi.2012.12

Lõhmussaar, K., Oka, R., Espejo Valle-Inclan, J., Smits, M. H. H., Wardak, H., Korving, J., et al. (2021). Patient-Derived Organoids Model Cervical Tissue Dynamics and Viral Oncogenesis in Cervical Cancer. Cell Stem Cell. 28, 13801396.e1386. doi: 10.1016/j.stem.2021.03.012

Lotz, C., Kiesewetter, L., Schmid, F. F., Hansmann, J., Walles, H., and GroeberBecker, F. (2018). Replacing the Draize Eye Test: Impedance Spectroscopy as a 3R Method to Discriminate Between All GHS Categories for Eye Irritation. Sci. Rep. 8, 15049. doi: 10.1038/s41598-018-33118-2

Lotz, C., Schmid, F. F., Rossi, A., Kurdyn, S., Kampik, D., De Wever, B., et al. (2016). Alternative Methods for the Replacement of Eye Irritation Testing. Altex 33, 55-67. doi: 10.14573/altex.1508241

Lucas, C. T., Chandler, F. Jr., Martin, J. E. Jr., and Schmale, J. D. (1971). Transfer of Gonococcal Urethritis From Man to Chimpanzee. An Animal Model for Gonorrhea. JAMA 216, 1612-1614. doi: 10.1001/jama.1971.03180360058007

Maisey, K., Nardocci, G., Imarai, M., Cardenas, H., Rios, M., Croxatto, H. B., et al. (2003). Expression of Proinflammatory Cytokines and Receptors by Human Fallopian Tubes in Organ Culture Following Challenge With Neisseria Gonorrhoeae. Infect. Immun. 71, 527-532. doi: 10.1128/IAI.71.1.527-532.2003

Martins Gomes, S. F., Westermann, A. J., Sauerwein, T., Hertlein, T., Förstner, K. U., Ohlsen, K., et al. (2019). Induced Pluripotent Stem Cell-Derived Brain Endothelial Cells as a Cellular Model to Study Neisseria Meningitidis Infection. Front. Microbiol. 10. doi: 10.3389/fmicb.2019.01181

Maru, Y., Kawata, A., Taguchi, A., Ishii, Y., Baba, S., Mori, M., et al. (2020). Establishment and Molecular Phenotyping of Organoids From the Squamocolumnar Junction Region of the Uterine Cervix. Cancers (Basel) 12, 694. doi: 10.3390/cancers12030694

Massie, I., Spaniol, K., Barbian, A., Poschmann, G., Stühler, K., Geerling, G., et al. (2017). Evaluation of Decellularized Porcine Jejunum as a Matrix for Lacrimal Gland Reconstruction In Vitro for Treatment of Dry Eye Syndrome. Invest. Ophthalmol. Vis. Sci. 58, 5564-5574. doi: 10.1167/iovs.16-20759

McGee, Z. A., Johnson, A. P., and Taylor-Robinson, D. (1981). Pathogenic Mechanisms of Neisseria Gonorrhoeae: Observations on Damage to Human Fallopian Tubes in Organ Culture by Gonococci of Colony Type 1 or Type 4. J. Infect. Dis. 143, 413-422. doi: 10.1093/infdis/143.3.413

Merz, A. J., Rifenbery, D. B., Arvidson, C. G., and So, M. (1996). Traversal of a Polarized Epithelium by Pathogenic Neisseriae: Facilitation by Type IV Pili and Maintenance of Epithelial Barrier Function. Mol. Med. 2, 745-754. doi: 10.1007/BF03401658

Miller, K. E. (2006). Diagnosis and Treatment of Neisseria Gonorrhoeae Infections. Am. Fam Physician. 73, 1779-1784.

Miller, C. P., Drell, M. J., Moeller, V., and Bohnhoff, M. (1945). Experimental Gonococcal Infection of the Rabbit's Eye, Method of Production. J. Infect. Dis. 77, 193-200. doi: 10.1093/infdis/77.3.193

Mills, M., and Estes, M. K. (2016). Physiologically Relevant Human Tissue Models for Infectious Diseases. Drug Discovery Today 21, 1540-1552. doi: 10.1016/ j.drudis.2016.06.020

Mirmonsef, P., Gilbert, D., Zariffard, M. R., Hamaker, B. R., Kaur, A., Landay, A. L., et al. (2011). The Effects of Commensal Bacteria on Innate Immune Responses in the Female Genital Tract. Am. J. Reprod. Immunol. 65, 190195. doi: $10.1111 / j .1600-0897.2010 .00943 . x$

Morales, P., Reyes, P., Vargas, M., Rios, M., Imarai, M., Cardenas, H., et al. (2006). Infection of Human Fallopian Tube Epithelial Cells With Neisseria Gonorrhoeae Protects Cells From Tumor Necrosis Factor Alpha-Induced Apoptosis. Infect. Immun. 74, 3643-3650. doi: 10.1128/iai.00012-06

Mosleh, I. M., Boxberger, H. J., Sessler, M. J., and Meyer, T. F. (1997). Experimental Infection of Native Human Ureteral Tissue With Neisseria Gonorrhoeae: Adhesion, Invasion, Intracellular Fate, Exocytosis, and Passage Through a Stratified Epithelium. Infect. Immun. 65, 3391-3398. doi: 10.1128/ iai.65.8.3391-3398.1997

Mosleh, I. M., Huber, L. A., Steinlein, P., Pasquali, C., Günther, D., and Meyer, T. F. (1998). Neisseria Gonorrhoeae Porin Modulates Phagosome Maturation. J. Biol. Chem. 273, 35332-35338. doi: 10.1074/jbc.273.52.35332

Moussavi-Harami, S. F., Mladinich, K. M., Sackmann, E. K., Shelef, M. A., Starnes, T. W., Guckenberger, D. J., et al. (2016). Microfluidic Device for Simultaneous Analysis of Neutrophil Extracellular Traps and Production of Reactive Oxygen Species. Integr. Biol. (Camb). 8, 243-252. doi: 10.1039/c5ib00225g
Muench, D. F., Kuch, D. J., Wu, H., Begum, A. A., Veit, S. J., Pelletier, M. E., et al. (2009). Hydrogen Peroxide-Producing Lactobacilli Inhibit Gonococci In Vitro But Not During Experimental Genital Tract Infection. J. Infect. Dis. 199, 13691378. doi: $10.1086 / 597390$

Muenzner, P., Bachmann, V., Zimmermann, W., Hentschel, J., and Hauck, C. R. (2010). Human-Restricted Bacterial Pathogens Block Shedding of Epithelial Cells by Stimulating Integrin Activation. Science 329, 1197-1201. doi: 10.1126/ science.1190892

Muenzner, P., and Hauck, C. R. (2020). Neisseria Gonorrhoeae Blocks Epithelial Exfoliation by Nitric-Oxide-Mediated Metabolic Cross Talk to Promote Colonization in Mice. Cell Host Microbe 27, 793-808.e795. doi: 10.1016/ j.chom.2020.03.010

Naumann, M., Wessler, S., Bartsch, C., Wieland, B., and Meyer, T. F. (1997). Neisseria Gonorrhoeae Epithelial Cell Interaction Leads to the Activation of the Transcription Factors Nuclear Factor kappaB and Activator Protein 1 and the Induction of Inflammatory Cytokines. J. Exp. Med. 186, 247-258. doi: 10.1084/jem.186.2.247

Ng, K. Y. B., Mingels, R., Morgan, H., Macklon, N., and Cheong, Y. (2018). In Vivo Oxygen, Temperature and $\mathrm{pH}$ Dynamics in the Female Reproductive Tract and Their Importance in Human Conception: A Systematic Review. Hum. Reprod. Update. 24, 15-34. doi: 10.1093/humupd/dmx028

Noguchi, K., Tsukumi, K., and Urano, T. (2003). Qualitative and Quantitative Differences in Normal Vaginal Flora of Conventionally Reared Mice, Rats, Hamsters, Rabbits, and Dogs. Comp. Med. 53, 404-412.

Novotny, P., Broughton, E. S., Cownley, K., Hughes, M., and Turner, W. H. (1978). Strain Related Infectivity of Neisseria Gonorrhoeae for the Guinea-Pig Subcutaneous Chamber and the Variability of the Immune Resistance in Different Breeds of Guinea-Pig. Br. J. Vener Dis. 54, 88-96. doi: 10.1136/ sti.54.2.88

Odeleye, A. O. O., Baudequin, T., Chui, C.-Y., Cui, Z., and Ye, H. (2020). An Additive Manufacturing Approach to Bioreactor Design for Mesenchymal Stem Cell Culture. Biochem. Eng. J. 156, 107515. doi: 10.1016/j.bej.2020.107515

Ortiz, M. C., Lefimil, C., Rodas, P. I., Vernal, R., Lopez, M., Acuña-Castillo, C., et al. (2015). Neisseria Gonorrhoeae Modulates Immunity by Polarizing Human Macrophages to a M2 Profile. PLoS One 10, e0130713. doi: 10.1371/ journal.pone. 0130713

Pan, C., Kumar, C., Bohl, S., Klingmueller, U., and Mann, M. (2009). Comparative Proteomic Phenotyping of Cell Lines and Primary Cells to Assess Preservation of Cell Type-Specific Functions. Mol. Cell Proteomics. 8, 443-450. doi: 10.1074/ mcp.M800258-MCP200

Pantelic, M., Chen, I., Parker, J., Zhang, P., Grunert, F., and Chen, T. (2004). Retinoic Acid Treated HL60 Cells Express CEACAM1 (CD66a) and Phagocytose Neisseria Gonorrhoeae. FEMS Immunol. Med. Microbiol. 42, 261-266. doi: 10.1016/j.femsim.2004.05.010

Pantelic, M., Kim, Y.-J., Bolland, S., Chen, I., Shively, J., and Chen, T. (2005). Neisseria Gonorrhoeae Kills Carcinoembryonic Antigen-Related Cellular Adhesion Molecule 1 (CD66a)-Expressing Human B Cells and Inhibits Antibody Production. Infect. Immun. 73, 4171-4179. doi: 10.1128/ IAI.73.7.4171-4179.2005

Park, J. H., Moon, S. H., Kang, D. H., Um, H. J., Kang, S. S., Kim, J. Y., et al. (2018). Diquafosol Sodium Inhibits Apoptosis and Inflammation of Corneal Epithelial Cells Via Activation of Erk1/2 and RSK: In Vitro and In Vivo Dry Eye Model. Invest. Ophthalmol. Vis. Sci. 59, 5108-5115. doi: 10.1167/iovs.17-22925

Priyadarsini, S., Nicholas, S. E., and Karamichos, D. (2018). 3d Stacked Construct: A Novel Substitute for Corneal Tissue Engineering. Methods Mol. Biol. 1697, 173-180. doi: 10.1007/7651_2017_23

Quillin, S. J., and Seifert, H. S. (2018). Neisseria Gonorrhoeae Host Adaptation and Pathogenesis. Nat. Rev. Microbiol. 16, 226-240. doi: 10.1038/nrmicro.2017.169

Rajaiya, J., Zhou, X., Barequet, I., Gilmore, M. S., and Chodosh, J. (2015). Novel Model of Innate Immunity in Corneal Infection. In Vitro Cell Dev. Biol. Anim. 51, 827-834. doi: 10.1007/s11626-015-9910-2

Rees, E., Tait, I. A., Hobson, D., Byng, R. E., and Johnson, F. W. (1977). Neonatal Conjunctivitis Caused by Neisseria Gonorrhoeae and Chlamydia Trachomatis. Br. J. Vener Dis. 53, 173-179. doi: 10.1136/sti.53.3.173

Reichl, S., and Müller-Goymann, C. C. (2003). The Use of a Porcine Organotypic Cornea Construct for Permeation Studies From Formulations Containing Befunolol Hydrochloride. Int. J. Pharm. 250, 191-201. doi: 10.1016/s03785173(02)00541-0 
Reimer, A., Seufert, F., Weiwad, M., Ebert, J., Bzdyl, N. M., Kahler, C. M., et al. (2016). Inhibitors of Macrophage Infectivity Potentiator-Like PPIases Affect Neisserial and Chlamydial Pathogenicity. Int. J. Antimicrob. Agents. 48, 401408. doi: 10.1016/j.ijantimicag.2016.06.020

Reyes, P. A., Vargas, M. F., García, K. P., Rubilar, P. S., Navarrete, P. A., Fuentes, P. M., et al. (2007). Apoptosis Related Genes Expressed in Cultured Fallopian Tube Epithelial Cells Infected In Vitro With Neisseria Gonorrhoeae. Biol. Res. 40, 319-327. doi: 10.4067/S0716-97602007000400006

Reynolds, L. P., Killilea, S. D., and Redmer, D. A. (1992). Angiogenesis in the Female Reproductive System. FASEB J. 6, 886-892. doi: 10.1046/j.13652613.2002.00277.x

Richardson, I. M., Calo, C. J., and Hind, L. E. (2021). Microphysiological Systems for Studying Cellular Crosstalk During the Neutrophil Response to Infection. Front. Immunol. 12, 1445. doi: 10.3389/fimmu.2021.661537

Ritter, J. L., and Genco, C. A. (2018). Neisseria Gonorrhoeae-Induced Inflammatory Pyroptosis in Human Macrophages is Dependent on Intracellular Gonococci and Lipooligosaccharide. J. Cell Death. 11, 1179066017750902. doi: 10.1177/1179066017750902

Rodríguez-Tirado, C., Maisey, K., Rodríguez, F. E., Reyes-Cerpa, S., Reyes-López, F. E., and Imarai, M. (2012). Neisseria Gonorrhoeae Induced Disruption of Cell Junction Complexes in Epithelial Cells of the Human Genital Tract. Microbes Infect. 14, 290-300. doi: 10.1016/j.micinf.2011.11.002

Rönnqvist, P. D., Forsgren-Brusk, U. B., and Grahn-Håkansson, E. E. (2006). Lactobacilli in the Female Genital Tract in Relation to Other Genital Microbes and Vaginal pH. Acta Obstet Gynecol Scand. 85, 726-735. doi: 10.1080/ 00016340600578357

Rowley, J., Vander Hoorn, S., Korenromp, E., Low, N., Unemo, M., Abu-Raddad, L. J., et al. (2019). Chlamydia, Gonorrhoea, Trichomoniasis and Syphilis: Global Prevalence and Incidence Estimates 2016. Bull. World Health Organ. 97, 548-562. doi: 10.2471/blt.18.228486

Rubin, D. H. F., Ross, J. D. C., and Grad, Y. H. (2020). The Frontiers of Addressing Antibiotic Resistance in Neisseria Gonorrhoeae. Transl. Res. 220, 122-137. doi: 10.1016/j.trsl.2020.02.002

Rudel, T., van Putten, J. P., Gibbs, C. P., Haas, R., and Meyer, T. F. (1992). Interaction of Two Variable Proteins (PilE and PilC) Required for PilusMediated Adherence of Neisseria Gonorrhoeae to Human Epithelial Cells. Mol. Microbiol. 6, 3439-3450. doi: 10.1111/j.1365-2958.1992.tb02211.x

Sato, T., Vries, R. G., Snippert, H. J., van de Wetering, M., Barker, N., Stange, D. E., et al. (2009). Single Lgr5 Stem Cells Build Crypt-Villus Structures In Vitro Without a Mesenchymal Niche. Nature 459, 262-265. doi: 10.1038/nature07935

Scheuerpflug, I., Rudel, T., Ryll, R., Pandit, J., and Meyer, T. F. (1999). Roles of PilC and PilE Proteins in Pilus-Mediated Adherence of Neisseria Gonorrhoeae and Neisseria Meningitidis to Human Erythrocytes and Endothelial and Epithelial Cells. Infect. Immun. 67, 834-843. doi: 10.1128/iai.67.2.834-843.1999

Schleimer, R. P., Kato, A., Kern, R., Kuperman, D., and Avila, P. C. (2007). Epithelium: At the Interface of Innate and Adaptive Immune Responses. J. Allergy Clin. Immunol. 120, 1279-1284. doi: 10.1016/j.jaci.2007.08.046

Semchenko, E. A., Everest-Dass, A. V., Jen, F. E., Mubaiwa, T. D., Day, C. J., and Seib, K. L. (2019). Glycointeractome of Neisseria Gonorrhoeae: Identification of Host Glycans Targeted by the Gonococcus To Facilitate Adherence to Cervical and Urethral Epithelial Cells. mBio 10, e01339-19. doi: 10.1128/ mBio.01339-19

Sharif, R., Priyadarsini, S., Rowsey, T. G., Ma, J. X., and Karamichos, D. (2018). Corneal Tissue Engineering: An In Vitro Model of the Stromal-Nerve Interactions of the Human Cornea. J. Vis. Exp. 131, 56308. doi: 10.3791/56308

Shaw, J. H., and Falkow, S. (1988). Model for Invasion of Human Tissue Culture Cells by Neisseria Gonorrhoeae. Infect. Immun. 56, 1625-1632. doi: 10.1128/ iai.56.6.1625-1632.1988

Shiju, T. M., Carlos de Oliveira, R., and Wilson, S. E. (2020). 3d In Vitro Corneal Models: A Review of Current Technologies. Exp. Eye Res. 200, 108213. doi: $10.1016 /$ j.exer.2020.108213

Shi, L., and Ronfard, V. (2013). Biochemical and Biomechanical Characterization of Porcine Small Intestinal Submucosa (SIS): A Mini Review. Int. J. Burns Trauma. 3, 173-179.

Shukla, V., Barnhouse, V., Ackerman, W., Summerfield, T. L., Powell, H. M., Leight, J. L., et al. (2018). Cellular Mechanics of Primary Human Cervical Fibroblasts: Influence of Progesterone and a Pro-Inflammatory Cytokine. Ann. BioMed. Eng. 46, 197-207. doi: 10.1007/s10439-017-1935-0
Simons, M. P., Nauseef, W. M., and Apicella, M. A. (2005). Interactions of Neisseria Gonorrhoeae With Adherent Polymorphonuclear Leukocytes. Infect. Immun. 73, 1971-1977. doi: 10.1128/iai.73.4.1971-1977.2005

Song, W., Condron, S., Mocca, B. T., Veit, S. J., Hill, D., Abbas, A., et al. (2008). Local and Humoral Immune Responses Against Primary and Repeat Neisseria Gonorrhoeae Genital Tract Infections of 17beta-Estradiol-Treated Mice. Vaccine 26, 5741-5751. doi: 10.1016/j.vaccine.2008.08.020

So, N. S. Y., Ostrowski, M. A., and Gray-Owen, S. D. (2012). Vigorous Response of Human Innate Functioning IgM Memory B Cells Upon Infection by Neisseria Gonorrhoeae<. J. Immunol. 188, 4008-4022. doi: 10.4049/jimmunol.1100718

Steichen, C. T., Shao, J. Q., Ketterer, M. R., and Apicella, M. A. (2008). Gonococcal Cervicitis: A Role for Biofilm in Pathogenesis. J. Infect. Dis. 198, 1856-1861. doi: 10.1086/593336

Steinke, M., Gross, R., Walles, H., Gangnus, R., Schütze, K., and Walles, T. (2014). An Engineered 3D Human Airway Mucosa Model Based on an SIS Scaffold. Biomaterials 35, 7355-7362. doi: 10.1016/j.biomaterials.2014.05.031

Stevens, J. S., and Criss, A. K. (2018). Pathogenesis of Neisseria Gonorrhoeae in the Female Reproductive Tract: Neutrophilic Host Response, Sustained Infection, and Clinical Sequelae. Curr. Opin. Hematol. 25, 13-21. doi: 10.1097/moh.0000000000000394

Stevens, J. S., Gray, M. C., Morisseau, C., and Criss, A. K. (2018). Endocervical and Neutrophil Lipoxygenases Coordinate Neutrophil Transepithelial Migration to Neisseria Gonorrhoeae. J. Infect. Dis. 218, 1663-1674. doi: 10.1093/infdis/jiy347

Stohl, E. A., Dale, E. M., Criss, A. K., and Seifert, H. S. (2013). Neisseria Gonorrhoeae Metalloprotease NGO1686 is Required for Full Piliation, and Piliation is Required for Resistance to $\mathrm{H} 2 \mathrm{O} 2$ - and Neutrophil-Mediated Killing. mBio 4, e00399-13. doi: 10.1128/mBio.00399-13

Streeter, P. R., and Corbeil, L. B. (1981). Gonococcal Infection in EndotoxinResistant and Endotoxin-Susceptible Mice. Infect. Immun. 32, 105-110. doi: 10.1128/iai.32.1.105-110.1981

Swanson, K. V., Jarvis, G. A., Brooks, G. F., Barham, B. J., Cooper, M. D., and Griffiss, J. M. (2001). CEACAM is Not Necessary for Neisseria Gonorrhoeae to Adhere to and Invade Female Genital Epithelial Cells. Cell Microbiol. 3, 681691. doi: 10.1046/j.1462-5822.2001.00147.x

Taylor-Robinson, D., Furr, P. M., and Hetherington, C. M. (1990). Neisseria Gonorrhoeae Colonises the Genital Tract of Oestradiol-Treated Germ-Free Female Mice. Microb. Pathog. 9, 369-373. doi: 10.1016/0882-4010(90)90071-w

Thongthai, C., and Sawyer, W. D. (1973). Studies on the Virulence of Neisseria Gonorrhoeae. I. Relation of Colonial Morphology and Resistance to Phagocytosis by Polymorphonuclear Leukocytes. Infect. Immun. 7, 373-379. doi: 10.1128/iai.7.3.373-379.1973

Timmerman, M. M., Shao, J. Q., and Apicella, M. A. (2005). Ultrastructural Analysis of the Pathogenesis of Neisseria Gonorrhoeae Endometrial Infection. Cell Microbiol. 7, 627-636. doi: 10.1111/j.1462-5822.2005.00491.x

Tjia, K. F., van Putten, J. P., Pels, E., and Zanen, H. C. (1988). The Interaction Between Neisseria Gonorrhoeae and the Human Cornea in Organ Culture. An Electron Microscopic Study. Graefes Arch. Clin. Exp. Ophthalmol. 226, 341345. doi: 10.1007/bf02172964

Turco, M. Y., Gardner, L., Hughes, J., Cindrova-Davies, T., Gomez, M. J., Farrell, L., et al. (2017). Long-Term, Hormone-Responsive Organoid Cultures of Human Endometrium in a Chemically Defined Medium. Nat. Cell Biol. 19, 568-577. doi: $10.1038 /$ ncb3516

Unemo, M., and Shafer, W. M. (2011). Antibiotic Resistance in Neisseria Gonorrhoeae: Origin, Evolution, and Lessons Learned for the Future. Ann. N Y Acad. Sci. 1230, E19-E28. doi: 10.1111/j.1749-6632.2011.06215.x

Unger, R. E., Krump-Konvalinkova, V., Peters, K., and Kirkpatrick, C. J. (2002). In Vitro Expression of the Endothelial Phenotype: Comparative Study of Primary Isolated Cells and Cell Lines, Including the Novel Cell Line HPMEC-ST1.6R. Microvasc. Res. 64, 384-397. doi: 10.1006/mvre.2002.2434

van Vliet, S. J., Steeghs, L., Bruijns, S. C. M., Vaezirad, M. M., Snijders Blok, C., Arenas Busto, J. A., et al. (2009). Variation of Neisseria Gonorrhoeae Lipooligosaccharide Directs Dendritic Cell-Induced T Helper Responses. PLoS Pathog. 5, e1000625. doi: 10.1371/journal.ppat.1000625

Waitkins, S. A., and Flynn, J. (1973). Intracellular Growth and Type Variation of Neisseria Gonorrhoeae in Tissue Cell-Cultures. J. Med. Microbiol. 6, 399-403. doi: 10.1099/00222615-6-3-399

Wang, D., Ding, X., Xue, W., Zheng, J., Tian, X., Li, Y., et al. (2017a). A New Scaffold Containing Small Intestinal Submucosa and Mesenchymal Stem Cells Improves Pancreatic Islet Function and Survival In Vitro and In Vivo. Int. J. Mol. Med. 39, 167-173. doi: 10.3892/ijmm.2016.2814 
Wang, S., Ghezzi, C. E., Gomes, R., Pollard, R. E., Funderburgh, J. L., and Kaplan, D. L. (2017c). In Vitro 3D Corneal Tissue Model With Epithelium, Stroma, and Innervation. Biomaterials 112, 1-9. doi: 10.1016/j.biomaterials.2016.09.030

Wang, J., Gray-Owen, S. D., Knorre, A., Meyer, T. F., and Dehio, C. (1998). Opa Binding to Cellular CD66 Receptors Mediates the Transcellular Traversal of Neisseria Gonorrhoeae Across Polarized T84 Epithelial Cell Monolayers. Mol. Microbiol. 30, 657-671. doi: 10.1046/j.1365-2958.1998.01102.x

Wang, J. A., Meyer, T. F., and Rudel, T. (2008). Cytoskeleton and Motor Proteins are Required for the Transcytosis of Neisseria Gonorrhoeae Through Polarized Epithelial Cells. Int. J. Med. Microbiol. 298, 209-221. doi: 10.1016/ j.ijmm.2007.05.004

Wang, F., Song, Q., Du, L., and Wu, X. (2020). Development and Characterization of an Acellular Porcine Small Intestine Submucosa Scaffold for Use in Corneal Epithelium Tissue Engineering. Curr. Eye Res. 45, 134-143. doi: 10.1080/ 02713683.2019.1663386

Wang, L. C., Yu, Q., Edwards, V., Lin, B., Qiu, J., Turner, J. R., et al. (2017b). Neisseria Gonorrhoeae Infects the Human Endocervix by Activating nonMuscle Myosin II-Mediated Epithelial Exfoliation. PLoS Pathog. 13, e1006269. doi: 10.1371/journal.ppat.1006269

Ward, M. E., and Watt, P. J. (1972). Adherence of Neisseria Gonorrhoeae to Urethral Mucosal Cells: An Electron-Microscopic Study of Human Gonorrhea. J. Infect. Dis. 126, 601-605. doi: 10.1093/infdis/126.6.601

Ward, M. E., Watt, P. J., and Robertson, J. N. (1974). The Human Fallopian Tube: A Laboratory Model for Gonococcal Infection. J. Infect. Dis. 129, 650-659. doi: 10.1093/infdis/129.6.650

Warner, D. M., Folster, J. P., Shafer, W. M., and Jerse, A. E. (2007). Regulation of the MtrC-MtrD-MtrE Efflux-Pump System Modulates the In Vivo Fitness of Neisseria Gonorrhoeae. J. Infect. Dis. 196, 1804-1812. doi: 10.1086/522964

Watt, P. J. (1970). The Fate of Gonococci in Polymorphonuclear Leucocytes. J. Med. Microbiol. 3, 501-509. doi: 10.1099/00222615-3-3-501

Wira, C. R., Grant-Tschudy, K. S., and Crane-Godreau, M. A. (2005). Epithelial Cells in the Female Reproductive Tract: A Central Role as Sentinels of Immune Protection. Am. J. Reprod. Immunol. 53, 65-76. doi: 10.1111/j.1600-0897.2004.00248.x

Wong, K. H., Arko, R. J., Schalla, W. O., and Steurer, F. J. (1979). Immunological and Serological Diversity of Neisseria Gonorrhoeae: Identification of New Immunotypes and Highly Protective Strains. Infect. Immun. 23, 717-722. doi: 10.1128/iai.23.3.717-722.1979

Woods, C. R. (2005). Gonococcal Infections in Neonates and Young Children. Semin. Pediatr. Infect. Dis. 16, 258-270. doi: 10.1053/j.spid.2005.06.006

Xiao, S., Coppeta, J. R., Rogers, H. B., Isenberg, B. C., Zhu, J., Olalekan, S. A., et al. (2017). A Microfluidic Culture Model of the Human Reproductive Tract and 28-Day Menstrual Cycle. Nat. Commun. 8, 14584. doi: 10.1038/ncomms14584

Xu, S. X., Leontyev, D., Kaul, R., and Gray-Owen, S. D. (2018). Neisseria Gonorrhoeae Co-Infection Exacerbates Vaginal HIV Shedding Without Affecting Systemic Viral Loads in Human CD34+ Engrafted Mice. PLoS One 13, e0191672. doi: 10.1371/journal.pone.0191672
Yang, T., Heydarian, M., Kozjak-Pavlovic, V., Urban, M., Harbottle, R. P., and Rudel, T. (2020). Folliculin Controls the Intracellular Survival and TransEpithelial Passage of Neisseria Gonorrhoeae. Front. Cell Infect. Microbiol. 10. doi: $10.3389 /$ fcimb.2020.00422

Yang, K., Wu, J., Xu, G., Xie, D., Peretz-Soroka, H., Santos, S., et al. (2017). A DualDocking Microfluidic Cell Migration Assay (D(2)-Chip) for Testing Neutrophil Chemotaxis and the Memory Effect. Integr. Biol. (Camb). 9, 303312. doi: 10.1039/c7ib00037e

Yu, Q., Wang, L. C., Di Benigno, S., Gray-Owen, S. D., Stein, D. C., and Song, W. (2019). Neisseria Gonorrhoeae Infects the Heterogeneous Epithelia of the Human Cervix Using Distinct Mechanisms. PLoS Pathog. 15, e1008136. doi: 10.1371/journal.ppat.1008136

Zenni, M. K., Giardina, P. C., Harvey, H. A., Shao, J., Ketterer, M. R., Lubaroff, D. M., et al. (2000). Macropinocytosis as a Mechanism of Entry Into Primary Human Urethral Epithelial Cells by Neisseria Gonorrhoeae. Infect. Immun. 68, 1696-1699. doi: 10.1128/iai.68.3.1696-1699.2000

Zhang, C., Du, L., Sun, P., Shen, L., Zhu, J., Pang, K., et al. (2017). Construction of Tissue-Engineered Full-Thickness Cornea Substitute Using Limbal Epithelial Cell-Like and Corneal Endothelial Cell-Like Cells Derived From Human Embryonic Stem Cells. Biomaterials 124, 180-194. doi: 10.1016/ j.biomaterials.2017.02.003

Zhang, J., Li, G., Bafica, A., Pantelic, M., Zhang, P., Broxmeyer, H., et al. (2005). Neisseria Gonorrhoeae Enhances Infection of Dendritic Cells by HIV Type 1 . J. Immunol. 174, 7995-8002. doi: 10.4049/jimmunol.174.12.7995

Zhu, W., Ventevogel, M. S., Knilans, K. J., Anderson, J. E., Oldach, L. M., McKinnon, K. P., et al. (2012). Neisseria Gonorrhoeae Suppresses Dendritic Cell-Induced, Antigen-Dependent CD4 T Cell Proliferation. PLoS One 7, e41260. doi: 10.1371/journal.pone.0041260

Conflict of Interest: The authors declare that the research was conducted in the absence of any commercial or financial relationships that could be construed as a potential conflict of interest.

Publisher's Note: All claims expressed in this article are solely those of the authors and do not necessarily represent those of their affiliated organizations, or those of the publisher, the editors and the reviewers. Any product that may be evaluated in this article, or claim that may be made by its manufacturer, is not guaranteed or endorsed by the publisher.

Copyright (c) 2022 Heydarian, Rühl, Rawal and Kozjak-Pavlovic. This is an openaccess article distributed under the terms of the Creative Commons Attribution License (CC BY). The use, distribution or reproduction in other forums is permitted, provided the original author(s) and the copyright owner(s) are credited and that the original publication in this journal is cited, in accordance with accepted academic practice. No use, distribution or reproduction is permitted which does not comply with these terms. 